\title{
A UNIFIED FRAMEWORK FOR RAND AND OTHER REASONABLE ROYALTIES
}

\author{
Jorge L. Contreras ${ }^{\dagger}$ and Richard J. Gilbert ${ }^{\dagger t}$ \\ "One question that I have been asked is, 'What's so special about \\ standard essential patents...??"1
}

\begin{abstract}
The framework for calculating "reasonable royalty" patent damages has evolved over the years to a point at which, today, it is viewed by many commentators as potentially misleading and untethered from its original purpose. We offer a proposal to modify the framework for determining reasonable patent royalties that is based on recent scholarly and judicial analyses of standard-essential patents that are subject to commitments to license on terms that are reasonable and non-discriminatory (RAND). Litigated cases have applied the traditional Georgia-Pacific factors to assess RAND royalty rates with modifications to account for the circumstances of the RAND commitment and the incremental value of allegedly infringed patents to the overall product offering. We propose that the reasonable royalty analysis should be conducted in essentially the same manner for all patents, whether or not they are encumbered by RAND commitments. We find considerable support for our approach in the historical development of U.S. patent law prior to the advent of the Georgia-Pacific test.
\end{abstract}

DOI: http://dx.doi.org/10.15779/Z38384R

(C) 2015 Jorge L. Contreras \& Richard J. Gilbert.

$\dagger$ Jorge L. Contreras is an Associate Professor of Law at S.J. Quinney College of Law at the University of Utah.

It Richard J. Gilbert is an Emeritus Professor of Economics and a Professor of the Graduate School at the University of California, Berkeley.

The authors served as members of the National Academy of Sciences' (NAS) Committee on IP in International Standards Setting, which produced the report PATENT CHALlENGES FOR STANDARD-SETTING IN THE GLOBAL ECONOMY (Keith Maskus \& Stephen A. Merrill, eds. 2013). The views expressed in this Article are solely the authors' and do not reflect the views of the Committee or the NAS. We are grateful to Thomas Cotter, David Jones, Mark Lemley, Oskar Liivak, Amy Marasco, Peter Menell, Robert Merges, Carl Shapiro, Norman Siebrasse, and David Taylor for helpful discussion and suggestions. Professor Gilbert acknowledges partial support from the Competition Policy Center at the University of California, Berkeley.

1. FIONA M. SCOTT-MORTON, DEPUTY ASSistant ATtORney GEN. For ECONOMiC ANALYSIS, ANTITRUST Division, U.S. DEP’T OF Justice, THE ROlE OF STANDARDS IN THE CURRENT PATENT WARS 5 (2012), available at http://www.justice .gov/atr/speech/role-standards-current-patent-wars. 


\section{TABLE OF CONTENTS}

INTRODUCTION 1453

I. ARE HOLDERS OF RAND-ENCUMBERED PATENTS ENTITLED TO SEEK INJUNCTIVE RELIEF? 1460

II. WHAT IS A REASONABLE ROYALTY? 1465

A. RAND AS A COMPROMISE BETWEEN LICENSORS AND LICENSEES. 1465

B. INCREMENTAL VALUE 1467

C. BARGAINING AFTER STANDARD ADOPTION ……………................ 1471

D. INCENTIVES FOR INVENTION ................................................................. 1472

III. THE LAW OF PATENT DAMAGES IN THE U.S.......................... 1473

A. Historical DeVelopment of Law of Patent Damages ...... 1475

1. Early History-The Need to Prove Actual Losses ........................... 1475

2. The Emergence of Reasonable Royalty Damages............................... 1476

3. Georgia-Pacific and the Hypothetical Negotiation ............................. 1479

B. RAND IN THE COURTS ……………………................................... 1482

IV. THE CASE FOR A UNIFIED FRAMEWORK FOR REASONABLE ROYALTIES 1486

A. PATENT Hold-Up Is A Risk FOR BOTH SEPS AND NONSEPS 1486

B. ROYALTY-STACKING IS NOT UNIQUE TO SEPS ................................ 1488

C. Timing of Hypothetical NegotiationsCONVERGING ON THE RAND ANALYSIS. 1491

D. INCONSISTENT TREATMENT OF PATENT INFRINGEMENT DAMAGES FOR SEPS AND NON-SEPS 1493

E. UNIFORMITY ENCOURAGES PARTICIPATION IN STANDARDSETTING. 1495

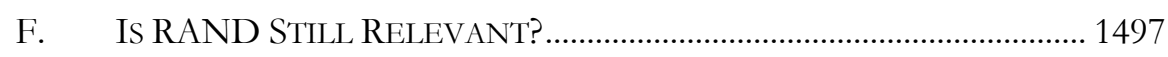

V. CALCULATING REASONABLE ROYALTIES: A NEW, OLD APPROACH TO PATENT DAMAGES 1498

A. INCREMENTAL VALUE REDUX............................................................. 1499

B. NeXt Best Alternative ................................................................ 1502

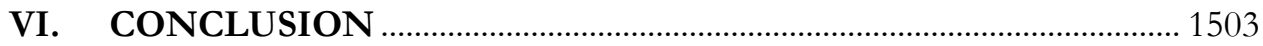




\section{INTRODUCTION}

Technical interoperability standards-known by familiar acronyms such as $\mathrm{Wi}-\mathrm{Fi}$, USB, HTTP, $3 \mathrm{G}$ and $4 \mathrm{G}$-enable products manufactured by different vendors to interoperate in a manner that is transparent to the consumer. These standards were developed by groups of engineers employed by different firms and institutions who collaborate, either in person or virtually, at one or more standard-setting organizations (SSOs). ${ }^{2}$ Many of these SSOs require owners of patents that are essential to practice a standard to license those patents on terms that are "reasonable and non-discriminatory" (RAND) or "fair, reasonable and nondiscriminatory" (FRAND or F/RAND). ${ }^{3}$

For example, the Bylaws of the Institute of Electrical and Electronics Engineers Standards Association (IEEE) ${ }^{4}$ describe a typical RAND licensing requirement for owners of patents that include claims that would be infringed by products that comply with a standard. ${ }^{5}$ Owners of such patents must submit a letter of assurance to IEEE containing a statement

2. SSOs include a broad range of organizations, from large, well-established bodies that address the standardization needs of major industry segments (e.g., the European Telecommunications Standards Institute (ETSI) (mobile telecommunications), the Institute of Electrical and Electronics Engineers (IEEE), and the Internet Engineering Task Force (IETF) (Internet protocols)), to smaller groups often referred to as "consortia" that focus on one or a handful of related standards (e.g., the HDMI Forum, Bluetooth Special Interest Group). We use the acronym SSOs to refer to both standardsetting organizations and standards developing organizations (SDOs). See generally Brad Biddle et al., The Expanding Role and Importance of Standards in the Information and Communications Technology Industry, 52 JURIMETRICS 177 (2012) (describing the standards-development “ecosystem"); AM. BAR Ass'N, STANDARDS DEVELOPMENT PATENT POLICY MANUAL ix-xi (Jorge L. Contreras ed., 2007) [hereinafter ABA PATENT POLICY MANUAL] (describing organizations involved in standard-setting).

3. We also use the term "RAND" to encompass commitments to license patents on terms that are both "reasonable and non-discriminatory" and those labeled "fair, reasonable and non-discriminatory" (FRAND), as commentators and courts have largely treated these terms as synonymous. See U.S. DeP'T OF Justice \& U.S. PATENT \& TRADEMARK OfFICE, POLICY STATEMENT ON REMEDIES FOR STANDARDESSENTIAL PATENTS SUBJECT TO VOLUNTARY F/RAND COMMITMENTS 1 n.2 (2013) [hereinafter DOJ/PTO POLICY STATEMENT], available at http://www.justice .gov/atr/public/guidelines/290994.pdf ("Commentators frequently use the terms "RAND" and "FRAND" interchangeably to denote the same substantive type of commitment.").

4. IEEE is a leading SSO that is responsible, among other things, for the ubiquitous 802.11 suite of wireless networking standards commonly referred to as "Wi-Fi." See IEEE STANDARDS AsSOCIATION, http://standards.ieee.org (last visited Mar. 4, 2015).

5. IEEE-SA Standards Board Bylaws $\$ 6.2$, IEEE, available at http://standards.ieee .org/develop/policies/bylaws/sb_bylaws.pdf [hereinafter IEEE Patent Policy]. 
that the patent owner will make available to all applicants a license for patent claims that are essential to the implementation of the standard either without compensation or under reasonable rates, with other reasonable terms and conditions that are demonstrably free of any unfair discrimination. ${ }^{6}$ We use the acronym SEP to refer to a standard-essential patent subject to a RAND commitment and non-SEP to refer to any other patent.

SSOs typically do not describe the specific terms of their RAND obligations and instead have largely deferred to their members, as well as the courts and competition enforcement agencies, to fill in the missing details. $^{7}$ For the most part, the published opinions of enforcement agencies and scholars have focused on what makes SEPs different from other patents. In particular, they have addressed the following questions:

- What are reasonable and non-discriminatory licensing terms and conditions, and, in particular, what is a RAND royalty?

6. Id.

7. Some standard-setting organizations require royalty-free licensing, while others require or allow patent holders to declare the maximum royalties and most restrictive licensing terms for their patents. For a description of the licensing commitments of a range of SSOs in the information and communications technologies (ICT) market, see RUDI BEKKERS \& ANDREW UPDEGROVE, A STUDY OF IPR POLICIES AND PRACTICES OF A REPRESENTATIVE GROUP OF STANDARD SETTING ORGANIZATIONS WORLDWIDE 27-30 (2012), available at http://sites.nationalacademies.org/ xpedio/groups/pgasite/documents/webpage/pga_072197.pdf (describing the policy commitment structures of ten major SDOs); Mark A. Lemley, Intellectual Property Rights and Standard-Setting Organizations, 90 CALIF. L. REV. 1889, 1925 (2002) (studying twenty-nine SSOs). The IEEE recently amended its patent policy to provide additional details regarding its interpretation of the RAND commitment contained in the policy. See News Releases: IEEE Statement Regarding Updating of its Standards-Related Patent Policy, IEEE (Feb. 8, 2015), http://www.ieee.org/about/news/2015/8_february _2015.html; see also Jorge L. Contreras, IEEE Amends its Patent (FRAND) Policy, PATENTLY-O (Feb. 9, 2015), http://patentlyo.com/patent/2015/02/amends-patent -policy.html.

8. See, e.g., ABA PATENT POLICY MANUAL, supra note 2, at 47-62; Dennis W. Carlton \& Allan L. Shampine, An Economic Interpretation of FRAND, $9 \mathrm{~J}$. Competition L. \& ECON. 531 (2013); Richard J. Gilbert, Deal or No Deal? Licensing Negotiations in Standard-Setting Organizations, 77 ANTITRUST L.J. 855, 859 (2011); Anne Layne-Farrar, A. Jorge Padilla \& Richard Schmalensee, Pricing Patents for Licensing in Standard-Setting Organizations: Making Sense of FRAND Commitments, 74 ANTITRUST L.J. 671 (2007); Doug Lichtman, Understanding the RAND Commitment, 47 Hous. L. REV. 1023, 1033 (2010); Joseph Scott Miller, Standard Setting, Patents, and Access Lock-In: RAND Licensing and the Theory of the Firm, 40 IND. L. REV. 351, 360 (2007); J. Gregory Sidak, The Meaning of FRAND, Part I: Royalties, 9 J. COMPETITION L. \& ECON. 931 (2013); Norman V. Siebrasse \& Thomas F. Cotter, The Value of the 
- Under what conditions, if any, does a RAND commitment allow a SEP owner to seek an injunction against infringement?

- Does a RAND commitment travel with the patent if the patent is assigned or transferred to another party? ${ }^{10}$

Where standard-setting organizations do not specify the details of RAND commitments or state their intended purposes, courts, regulatory agencies, and numerous commentators have interpreted the RAND commitments as mitigating possible opportunistic conduct when firms and consumers make investments that are specific to a standard. For example, a joint statement by the U.S. Department of Justice (DOJ), Antitrust Division, and the U.S. Patent \& Trademark Office (PTO) concluded that,

In an effort to reduce the occurrences of opportunistic conduct in the adoption of voluntary consensus standards, while encouraging participants to include the best available technology in standards, some SDOs have relied on voluntary licensing commitments by their participants, including commitments to

Standard (Univ. of Minn. Law School Legal Studies Research Paper Series, Research Paper No. 15-21, 2015), available at http://papers.ssrn.com/sol3/papers.cfm?abstract _id=2636445; J. Daniel G. Swanson \& William J. Baumol, Reasonable and Nondiscriminatory (RAND) Royalties, Standards Selection, and Control of Market Power, 73 ANTITRUST L.J. 1 (2005).

9. See, e.g., DOJ/PTO POLICY STATEMENT, supra note 3; BRIAN T. YeH, CONG. RESEARCH SERV., R42705, AVAILABILITY OF INJUNCTIVE RELIEF FOR STANDARDESSENTIAL PATENT HOLDERS (2012), available at http://www.law.berkeley.edu/files/ CRS_SEP_Report_9-2012.pdf; Colleen V. Chien \& Mark A. Lemley, Patent Holdup, the ITC, and the Public Interest, 98 CORNELL L. REV. 1 (2012); Colleen V. Chien et al., RAND Patents and Exclusion Orders: Submission of 19 Economics and Law Professors to the International Trade Commission (Santa Clara Univ. Legal Studies Research Paper No. 07-12, 2012), available at http://papers.ssrn.com/sol3/papers.cfm?abstract_id=2102865; Joseph Farrell, John Hayes, Carl Shapiro \& Theresa Sullivan, Standard Setting, Patents, and Hold-Up, 74 ANTITRUST L.J. 603, 616 (2007); Mark A. Lemley \& Carl Shapiro, Patent Holdup and Royalty Stacking, 85 TEX. L. REV. 1991 (2007); Doug Lichtman, supra note 8, at 1023; Suzanne Michel, Bargaining for RAND Royalties in the Shadow of Patent Remedies Law, 77 ANTITRUST L.J. 889 (2011).

10. See, e.g., NAT'L ReSEARCH COUNCIL, PATENT CHALlenges FOR STANDARD-SETTING IN THE GLOBAL ECONOMY: LESSONS FROM INFORMATION And Communications Technology 52-69 (Keith Maskus \& Stephen A. Merrill eds., 2013) [hereinafter NAS REPORT]; Jay P. Kesan \& Carol M. Hayes, FRAND's Forever: Standards, Patent Transfers, and Licensing Commitments, 89 IND. L.J. 231 (2014). 
license the patents they own that are essential to the standard on F/RAND terms. ${ }^{11}$

The DOJ/PTO statement specifically references patent hold-up. When a standard becomes established in the marketplace, it can be prohibitively costly to switch to a different technology within the established standard or to a different standard. As a result, the owner of the patented technology may gain the economic power to charge high royalties or impose burdensome licensing terms "ex post," after firms and consumers have made investments that are specific to a standard. The term "patent hold-up" refers to this opportunistic conduct by the patent owner. ${ }^{12}$

The central theme of this Article is that features of patents with RAND commitments, such as the potential for hold-up, are not unique to those patents and the framework to assess reasonable licensing terms should be common to all patents. In recent opinions regarding standardessential patents with RAND commitments, courts have noted the obligations implicit in a RAND commitment and have modified generally accepted approaches to estimate infringement damages. ${ }^{13}$ Yet a unique analytical approach to patent damages for RAND-encumbered patents obscures the common ground that these patents share with other patents. Hold-up is a potential concern for all patents when technology users make investments that are specific to the patented technology, whether or not the patents are standard-essential or encumbered by RAND commitments. ${ }^{14}$ Courts also have noted that it is necessary to apportion the value of products that infringe standard-essential patents to assess reasonable royalties. Apportionment is a relevant concern for all patents, whether standard-essential or not, if multiple patents or other assets are necessary to make, sell, or use a product. ${ }^{15}$

The ongoing debate over the meaning of a RAND commitment also addresses whether such a commitment provides an adequate return to

11. DOJ/PTO POLICY STATEMENT, supra note 3, at 5. The term F/RAND captures both RAND and FRAND commitments.

12. Id. at 4 .

13. See Microsoft Corp. v. Motorola, Inc., No. C10-1823JLR, 2013 WL 2111217 , (W.D. Wash. Apr. 25, 2013); In re Innovatio IP Ventures, LLC Patent Litig., No. 11C-9308, 2013 WL 5593609 (N.D. Ill. Oct. 3, 2013).

14. See, e.g., Carl Shapiro, Injunctions, Hold-Up, and Patent Royalties, 12 AM. L. \& ECON. REV. 280 (2010).

15. See infra note 63 and accompanying text. 
compensate innovators for their investments. ${ }^{16}$ Given that research and development is a sunk cost, proponents of low royalties may have latitude to interpret a RAND commitment to deny a reward to compensate these expenditures without inducing the patent owner to refuse to offer a license. Yet whether a reasonable royalty to remedy patent infringement is sufficient to cover the patent owner's costs is not a question that is unique to SEPs. The economic value of a patent is its incremental contribution relative to the next-best alternative. That economic value is the appropriate metric to evaluate a reasonable royalty for both SEPs and nonSEPs.

We argue that policy-makers and the courts have been searching for the key to assess patent infringement damages under the wrong lamppost. Rather than modify traditional approaches to assess infringement damages to account for the particular circumstances of SEPs with RAND commitments, the correct approach should account for relevant features of patented technologies regardless of whether the patents are SEPs or not. ${ }^{17}$

Outside the context of standard-setting, it is not uncommon for patent owners to make various commitments or "pledges" regarding their patents. ${ }^{18}$ These may include product and field of use restrictions, requirements that the licensee grant licenses back to the licensor for other patents, commitments not to assert under certain circumstances, commitments not to transfer patents to non-practicing entities, commitments not to seek injunctions against infringement, and commitments to treat licensees as most-favored customers. ${ }^{19}$ In this

16. This is implicit in the concern over "hold-out," which refers to a situation in which a potential licensee refuses to accept a patent license on reasonable terms that the patent holder has offered (i.e., it holds out for a lower (and presumably unreasonable) royalty). This phenomenon has also been called "reverse hold-up." See generally Colleen V. Chien, "Holding UP" and "Holding Out," (Santa Clara Univ. Legal Studies Research Paper Series, Working Paper No. 19-13, 2013), available at http://papers.ssrn.com/sol3/ papers.cfm?abstract_id=2318648; Thomas F. Cotter, The Comparative Law and Economics of Standard-Essential Patents and FRAND Royalties, 22 TEX. INTELL. PROP. L.J. 311, 347 (2014).

17. Note that not all patents that are essential to a standard necessarily have RAND commitments and not all patents with RAND commitments are necessarily essential to a standard. See Jorge L. Contreras, Patent Pledges, 47 ARIZ. ST. L.J. (forthcoming 2016), available at http://papers.ssrn.com/sol3/papers.cfm?abstract_id=2525947 (cataloging patent-based commitments both within and outside the standard-setting context).

18. See generally id.

19. For example, so-called "most-favored customer" terms require that the patent holder grant a particular licensee terms that are no less favorable than the terms granted to any other licensee. See, e.g., Cameron R. Sneddon, Licensee Beware: The Seventh Circuit Holds That A Patent License By Any Other Name Is Not The Same, 2 SEVEnTH CIRCUIT 
respect, a RAND commitment is simply one type of pledge that a patent holder may make with respect to his or her patents. ${ }^{20}$ The existence of patent pledges other than RAND commitments does not require a different framework for the evaluation of a reasonable royalty. Similarly, the existence of a RAND pledge does not require a different framework for the determination of a reasonable royalty. Instead, a common framework for infringement damages should accommodate the constraints implied by a RAND pledge as well as other patent pledges.

For disputes in U.S. courts, no special analysis is required to assess if and when a RAND commitment permits the patentee to seek an injunction that prevents the manufacture, use, or sale of infringing products. The principles of equity enumerated by the Supreme Court in eBay Inc. v. MercExchange, $L L C$ adequately describe the conditions under which every patent owner may be entitled to an injunction. ${ }^{21}$ These principles apply equally to SEPs and non-SEPs. Thus, while the existence of a RAND commitment may heavily weigh one or more eBay factors against granting an injunction, we show in Part I below that the four-part eBay analytical structure remains intact even for RAND-encumbered patents. ${ }^{22}$

The RAND issue that has consumed the most ink and pixels lately, however, is the methodology for determining the "reasonable royalty" that may not be exceeded in licenses granted by the patent holder to implementers of the associated standard. Various commentators have offered different approaches regarding the determination of reasonableness and reasonable royalty levels in particular. ${ }^{23}$ In this Article, we argue that if a patent owner is entitled to a reasonable royalty, the framework for the determination of "reasonable" should not differ for SEPs and non-SEPs, although that framework must account for the economic characteristics of patents that may give rise to opportunistic conduct. ${ }^{24}$ Our conclusion finds support in a journey to the origins of patent damages law, which provides justification for a theory of reasonableness that is applicable to all patents

REV. 796 (2007) (addressing whether a settlement affects a patent license with a mostfavored customer provision).

20. A RAND pledge is a commitment to offer a license on reasonable terms, while other pledges may condition the terms in a license agreement. Nonetheless, both types of pledges are comparable in that they both constrain the conduct of the licensor.

21. 547 U.S. 388, 391 (2006).

22. See infra Part I.

23. See references cited at note 8, supra.

24. Siebrasse \& Cotter, supra note 8, also advocate a consistent approach to patent royalty calculations for SEPs and non-SEPs, though their approach differs from ours. 
and is consistent with interpretations of RAND royalties advocated by enforcement agencies. ${ }^{25}$

The law of patent damages evolved over many decades and important legal precedents for determining "reasonable" patent royalties were established long before standard setting organizations adopted RAND commitments. The prevailing approach to patent damages generally applies the fifteen factors described in Georgia-Pacific Corp. v. U.S. Plywood Corp. ${ }^{26}$ This approach has not proven to be directly applicable to the assessment of reasonable royalties in RAND disputes. As a result, recent federal court opinions have modified the Georgia-Pacific factors to accommodate perceived unique characteristics of RAND commitments. ${ }^{27}$ While we are sympathetic with these judicial attempts to utilize the Georgia-Pacific framework to the greatest extent feasible, despite its shortcomings, it is our view that the unstructured and ill-defined GeorgiaPacific analysis tends to obscure the key issue in the patent royalty determination: the incremental contribution of the patented technology to the infringing product. By returning to the roots of patent damages law, it is possible to develop a new framework for assessing patent damages that borrows from the extensive analysis and commentary that has arisen in response to the perceived problem of hold-up by standard-essential patents. Most importantly, we would extend this reasoning to all patents, whether or not standard-essential or encumbered by RAND commitments.

Our analysis proceeds in several steps. First, we join a growing consensus that there is no material difference between SEPs and nonSEPs in terms of the methodology used to determine the availability of injunctive relief. We extend this reasoning to show that there is no appreciable difference between SEPs and non-SEPs in terms of the appropriate analysis to assess a reasonable royalty payable with respect to each. With this in mind, we reason that the damages analysis for patents, in general, should be guided by recent analysis of RAND-encumbered patents, inasmuch as the point at which royalties should be computed is the time at which the infringer is able to choose between alternative infringing and non-infringing implementations, rather than at the time of

25. See infra Section IV.A.

26. 318 F. Supp. 1116, 1120 (S.D.N.Y. 1970), modified and affd, 446 F.2d 295 (2d Cir. 1971), cert. denied, 404 U.S. 870 (1971).

27. See Microsoft Corp. v. Motorola, Inc., No. C10-1823JLR, 2013 WL 2111217 (W.D. Wash. Apr. 25, 2013); In re Innovatio IP Ventures, LLC, 2013 WL 5593609 (N.D. Ill. Oct. 3, 2013); see also infra Part IV. 
infringement. Moreover, we join a growing chorus of commentators who have urged the courts to dispense with the Georgia-Pacific "hypothetical negotiation" framework. ${ }^{28}$ We instead support the use of the tools of economic analysis to assess reasonable royalties based on the incremental value of the relevant patented technology.

Recent litigation to assess a reasonable royalty for alleged infringement of SEPs has focused on the incremental value of the patents and sought ways to measure that incremental value, including the need to apportion value when a standard embodies many SEPs. The courts have applied a framework that seeks to identify the incremental value of allegedly infringed SEPs, notwithstanding the empirical limitations of such a framework. The same should be done for all patents.

\section{ARE HOLDERS OF RAND-ENCUMBERED PATENTS ENTITLED TO SEEK INJUNCTIVE RELIEF?}

Returning to the IEEE patent policy, a typical RAND commitment is "A statement that a license . . will be made available" on RAND terms. ${ }^{29}$ Commentators have disputed whether such a commitment requires the patent owner merely to offer a license that its owner believes is on RAND terms, or whether a license must eventually be granted on RAND terms. ${ }^{30}$ If it is only the former, some argue that the patent owner may seek an injunction if the initial "reasonable" offer is declined. ${ }^{31}$

Superficially, it may appear that a RAND commitment is special, because absent a RAND commitment, a patent owner has no obligation to offer a license on any terms. However, the Supreme Court laid this alleged distinction to rest in eBay. Without regard to whether a patent is

28. See, e.g., Daralyn J. Durie \& Mark A. Lemley, A Structured Approach To Calculating Reasonable Royalties, 14 LEWIS \& CLARK L. REV. 627 (2010); Christopher B. Seaman, Reconsidering the Georgia-Pacific Standard for Reasonable Royalty Patent Damages, 2010 BYU L. REV. 1661 (2010); David O. Taylor, Using Reasonable Royalties to Value Patented Technology, 49 GA. L. REV. 79, 125-26 (2014).

29. IEEE PATENT POLICY, supra note 6.

30. Compare Janusz Ordover \& Allan Shampine, Implementing the FRAND Commitment, 14 ANTITRUST SOURCE, no. 1, Oct. 2014, at 1 (noting that a FRAND commitment cannot be interpreted to require only "good faith" negotiations), with Roger G. Brooks \& Damien Geradin, Interpreting and Enforcing the Voluntary FRAND Commitment, 9 INT'L J. IT STANDARDS \& STANDARDIZATION RES. 1, 2 (2011) (“[T]he role of a court is not to determine what 'fair and reasonable' terms would be, but whether the terms offered... fall outside the range of reasonableness contemplated by the FRAND commitment.").

31. See, e.g., Bo Vesterdorf, Antitrust Enforcement and Civil Rights: SEPs and FRAND Commitments, CPI ANTITRUST CHRONICLE, Aug. 2014, at 1. 
subject to a RAND commitment or any other licensing pledge, the Supreme Court ruled that the decision to grant or deny an injunction is an act of equitable discretion, the test for which requires a plaintiff to demonstrate:

(1) that it has suffered an irreparable injury;

(2) that remedies available at law are inadequate to compensate for that injury;

(3) that considering the balance of hardships between the plaintiff and defendant, a remedy in equity is warranted; and

(4) that the public interest would not be disserved by a permanent injunction. ${ }^{32}$

Some argue that these factors are sufficient to deny injunctive relief to the holder of a RAND-encumbered patent. ${ }^{33}$ The RAND commitment is a commitment to offer a license and therefore the patent owner has revealed that compensation is an adequate remedy for infringement. Moreover, an injunction likely would not serve the public interest if it allowed the owner of one or more essential patents to prevent the manufacture or sale of products that comply with a widely-adopted standard, as this would be contrary to the promotion of the social benefits accompanying broad usage of interoperability standards.

Yet reasonable people can disagree. ${ }^{34} \mathrm{~A}$ patentee may suffer irreparable injury if an implementer enjoys the benefit of a patented technology yet refuses to negotiate in good faith over royalty terms. This scenario has been referred to as "reverse hold-up" or "hold-out." ${ }^{35}$ The implementer may be a competitor of the patent owner and by stalling negotiations may obtain an irreversible advantage in the marketplace. Even if the patent owner ultimately can bring suit for damages, the implementer may not be

32. eBay Inc. v. MercExchange, LLC, 547 U.S. 388 (2006).

33. See, e.g., Brief of BSA as Amicus Curiae Supporting Plaintiff-Appellants, Apple Inc. v. Motorola, Inc., 757 F.3d 1286 (Fed. Cir. 2014) (No. 2012-1548), 2013 WL 1151023.

34. See, e.g., Douglas H. Ginsburg, Taylor M. Owings \& Joshua D. Wright, Enjoining Injunctions: The Case Against Antitrust Liability for Standard Essential Patent Holders Who Seek Injunctions, ANTITRUST SOURCE, Oct. 2014, at 1.

35. See, e.g., Gregor Langus, Vilen Lipatov \& Damien Neven, Standard-Essential Patents: Who Is Really Holding Up (And When)?, 9 J. COMP. L. \& ECON. 253 (2013); Joshua D. Wright, Comm'r, Fed. Trade Comm'n, SSOs, FRAND, and Antitrust: Lessons from the Economics of Incomplete Contracts, Address at The Center for the Protection of Intellectual Property Inaugural Academic Conference (Sept. 12, 2013), in 21 GEO. MASOn L. REV. 791 (2014). 
able to make the patent owner whole for the costs imposed by its recalcitrance. An injunction may be necessary in such circumstances to bring the implementer to the bargaining table.

The scenarios in which continued infringement of a RANDencumbered patent may or may not cause irreparable harm are complex. The key point is that courts, informed by the patent owner's RAND commitment, can take these special circumstances into account and apply the eBay factors to determine when an injunction is warranted. Special instructions from antitrust enforcement agencies and academic commentators are unnecessary.

Standard-essential patents with RAND commitments do not require a unique framework to evaluate infringement claims. The eBay factors apply to all patents. Suppose a patent is essential to comply with a standard, but the patent is not burdened with a RAND commitment. Patents that are essential to practice a standard embody concerns that justify RAND commitments, even if their owners have not made commitments to offer licenses on RAND terms. Would the test described in eBay permit an injunction to prevent the infringement of a standard-essential patent that lacks a RAND commitment? Although application of the eBay factors is less certain in this situation, it is still the case that an injunction would allow the patent owner to prevent the manufacture or sale of products that comply with the standard. The consequence of an injunction would depend on many factors, including the existence of close substitutes for products that implement the standard. However, if the failure to license a patent that is essential to a standard would allow its owner to hold up firms and consumers that are locked in to the standard with serious negative consequences for economic welfare, it would not require a delicate balancing of equities for a court to conclude that injunctive relief should not be available, regardless of whether the patent is subject to a RAND licensing commitment.

In Apple Inc. v. Motorola, Inc. the Federal Circuit considered Motorola's request for an injunction seeking to prevent Apple's sale of products allegedly infringing RAND-encumbered patents essential to certain wireless telecommunications standards. ${ }^{36}$ The trial court (Judge Posner, sitting by designation) denied Motorola's request, reasoning that a patent holder making a RAND commitment, by definition, has acknowledged that a monetary royalty would be adequate compensation

36. Apple Inc. v. Motorola, Inc., 757 F.3d 1286 (Fed. Cir. 2014). 
for a license to the patent, thereby eliminating any argument that the infringement would cause the patent holder irreparable harm under eBay. ${ }^{37}$

The Federal Circuit upheld Judge Posner's denial of Motorola's request for an injunction, but offered different reasoning. Though the panel was divided on several issues, all three judges concurred in Judge Reyna's statement in the majority opinion that "[t]o the extent that the district court applied a per se rule that injunctions are unavailable for SEPs, it erred." 38 Judge Reyna reasons that the eBay framework for analyzing injunctive relief "provides ample strength and flexibility for analyzing FRAND committed patents and industry standards in general," and finds no reason to create "a separate rule or analytical framework for addressing injunctions for FRAND-committed patents." ${ }^{39}$

Judge Reyna explains that under the eBay framework, "a patentee subject to FRAND commitments may have difficulty establishing irreparable harm." ${ }^{* 0}$ However, "an injunction may be justified where an infringer unilaterally refuses a FRAND royalty or unreasonably delays negotiations to the same effect." ${ }^{\text {11 }}$ With this in mind, he then goes on to apply the eBay "irreparable harm" test to Motorola's request and agrees with the district court that Motorola was not entitled to an injunction, given its commitment to license the patents in question on RAND terms. ${ }^{42}$

Of course the Supreme Court's precedent in eBay does not apply directly to administrative proceedings at the International Trade

37. Apple Inc. v. Motorola, Inc., 869 F. Supp. 2d 901, 913-14 (N.D. Ill. 2012), aff d in part, 757 F.3d 1286 (Fed. Cir. 2014).

38. Apple, $757 \mathrm{~F} .3 \mathrm{~d}$ at 1331.

39. Id at 1331-32.

40. Id. at 1332 .

41. Id. (citing DOJ/PTO POLICY STATEMENT, supra note 3, at 7-8).

42. It is in this last respect that the panel parted ways. Chief Judge Rader, dissenting-in-part, argued that a genuine issue of material fact existed regarding Apple's conduct with respect to the acceptance of a FRAND license from Motorola, and would have remanded the case for further fact finding on this issue. Id. at 1333-34 (Rader, C.J., dissenting-in-part). Judge Prost, concurring-in-part and dissenting-in-part, disagreed with the majority's suggestion that an alleged infringer's refusal to negotiate a license could serve as a basis for issuing an injunction on a FRAND-encumbered patent. $I d$. at 1342 (Prost, J., concurring-in-part and dissenting-in-part). She reasons that while a potential licensee's bad faith negotiation might justify an award of enhanced damages, the eBay "irreparable harm" test would nevertheless militate against granting an injunction on a FRAND-encumbered patent. $I d$. However, she concedes that an injunction might be appropriate if the patentee is unable to collect the damages to which it is entitled, for example, if the potential licensee refuses to pay a court-ordered damage award or is judgment-proof. Id. at 1343 . 
Commission (ITC), the situs of much recent patent litigation. Nevertheless, the ITC is required, in determining whether to issue an exclusion order preventing the importation of an infringing product, to assess whether such an order would harm the public interest. ${ }^{43}$ In making this determination, the ITC is required to consider the effect of the order on "the public health and welfare, competitive conditions in the United States economy, the production of like or directly competitive articles in the United States, and United States consumers." ${ }^{44}$

Both the Federal Trade Commission and academic commentators have urged the ITC to consider exclusions based on infringement of SEPs to be contrary to the public interest under this provision..$^{45}$ Recently, the Obama administration has also indicated that it disfavors ITC exclusion orders for SEPs when the orders do not hew to the analysis that would otherwise be conducted under $e B a y{ }^{46}$ In this regard, we do not view the administration's recent disapproval of the ITC's exclusion order against Apple to represent a case of SEP exceptionalism, but a mere indication that the application of eBay-like considerations to the ITC's "public interest" test weighs against the issuance of exclusion orders involving RAND-encumbered patents. Again, SEPs and non-SEPs should be treated on an equal footing.

It is likewise the case that U.S. precedent does not constrain decisions made in foreign jurisdictions. For these venues, arguments raised by various commentators regarding the appropriate circumstances for injunctive relief may have persuasive value. But the existence of these other venues does not justify a special framework to evaluate whether injunctive relief is appropriate for litigation of RAND-encumbered patents in U.S. courts.

43. 19 U.S.C. $§ 1337(d)(1)(2012)$.

44. $I d$.

45. See Third Party United States Federal Trade Commission's Statement on the Public Interest, Certain Gaming and Entertainment Consoles, Inv. No. 337-TA-752 (June 6, 2012); RAND Patents and Exclusion Orders: Submission of 19 Economics and Law Professors to the International Trade Commission, Certain Wireless Communications Devices, Inv. No. 337-TA-745 (July 9, 2012) (the authors were signatories to this submission).

46. See Letter from Michael B. G. Froman, Ambassador, U.S. Trade Rep., to Irving A. Williamson, Chairman, U.S. Int'1 Trade Comm'n (Aug. 3, 2013), available at http://ustr.gov/sites/default/files/08032013\%20Letter_1.PDF (filed in Certain Electronic Devices, Inv. No. 337-TA-794 (Aug. 5, 2013)). 


\section{WHAT IS A REASONABLE ROYALTY?}

Interpretations abound over the meaning of the RAND commitment. ${ }^{47}$ To address this question it is useful to distinguish economic concepts of fair and reasonable license terms from interpretations that can be inferred from the objectives of the participants in standard setting organizations that impose RAND licensing requirements. The latter interpretation derives from the political economy of standard setting in which the goal of consensus in the choice of a standard may extend to interpret a RAND commitment as a compromise between technology licensors and licensees. ${ }^{48}$ Economic concepts include the incremental value contributed by the patented technology and the bargaining that may take place ex post between licensors and licensees. ${ }^{49}$ In a sense, an important distinction for the various approaches is between what a RAND commitment "should" mean and what it "does" mean, and whether there is a relationship between the two.

\section{A. RAND AS a COMPROMise BETWEen Licensors AND LICENSEES}

In the standard-setting context, RAND commitments arise through voluntary private interactions among firms. They are imposed through SSO membership agreements, policies, bylaws, letters of assurance, and a variety of other private ordering mechanisms.$^{50}$ Notably, however, RAND commitments do not arise, in the first instance, through statute or regulation. They are the results of private interactions, and thus the meaning of the term "reasonable" as a matter of the law of contract, promissory estoppel, or whatever other legal theory may exist to render such commitments enforceable may be said to be whatever the relevant parties ascribed to that term at the time the commitment was made.

47. Compare Roger G. Brooks \& Damien Geradin, Interpreting and Enforcing the Voluntary FRAND Commitment, 9 INT'L J. IT STANDARDS \& STANDARDIZATION RES. 1 (2011) (stating that a FRAND obligation leaves wide latitude to private parties negotiating a license), with Farrell et al., supra note 9 (standing for the rule that the reasonable royalty is the incremental value of the patented technology).

48. See NAS REPORT, supra note 10 , at 28.

49. See id. at 61-62.

50. For a detailed breakdown of the mechanisms by which FRAND commitments and other patent pledges are made, see Jorge L. Contreras, A Market Reliance Theory for FRAND Commitments and Other Patent Pledges, 2015 UTAH L. REV. 479. 
The literal interpretation of a RAND commitment as a contract ${ }^{51}$ leads some authors to conclude that the commitment is defined by the intent of the parties to the commitment as well as the stated policies of the applicable SSO. ${ }^{52}$ This is no simple task as patent owners and implementers of standards in products often have different business perspectives and are likely to reach contrasting conclusions about the quantification of a reasonable patent royalty. Generally speaking, patent owners seek a return on their initial research and development investments, while implementers want low costs for manufacturing and selling standards-compliant products. If SSO members were required to specify the meaning of a RAND royalty, any compromise that the organization might reach likely would depend, inter alia, on the distribution of members according to their ownership shares of SEPs and their expected shares of sales of standard-complaint products, as well as the rules of the $\mathrm{SSO}$ for establishing consensus. ${ }^{53}$

Members of SSOs are likely to differ dramatically in their desired royalties and therefore in their assessments of royalty terms that are reasonable. For example, members who hold patents but do not sell standard-compliant products may desire high patent royalties to maximize their return on research and development investments, while those who primarily sell products may desire low royalties in order to maximize product sales. ${ }^{54}$ Accommodating the concerns of both patent owners and implementers requires delicate diplomacy. It is no surprise that a key element of this diplomacy is to defer to others to determine the intricate details of a RAND commitment.

51. There are reasons to question the broad application of common law contract theory to RAND and other patent pledges. See id. at 503-517 (noting the lack of formal attributes of contract accompanying many SSO RAND commitments, the indefiniteness of these commitments and the difficulty of applying the third party beneficiary doctrine in such settings).

52. See, e.g., Brooks \& Geradin, supra note 9; Joanna Tsai \& Joshua D. Wright, Standard Setting, Intellectual Property Rights, and the Role of Antitrust in Regulating Incomplete Contracts, 80 ANTITRUST L.J. 157 (2015).

53. Admittedly, some SSO members may have one foot in each camp, as the division between patent holders and implementers is a fuzzy one. Many product manufacturers also contribute substantial resources to the development of new technology and accumulate significant patent portfolios. Nonetheless, these differing business perspectives persist if implementers are mostly technology users and if innovators are mostly technology sellers.

54. See Jorge L. Contreras, Technical Standards and Ex Ante Disclosure: Results and Analysis of an Empirical Study, 53 JURIMETRICS 163, 206-07 (2013) (pointing out different motivations between "patent-centric" and "product-centric" firms). 
Thus an interpretative approach based on assumed private interactions of members of SSOs is likely to fail. As noted above, neither firms nor SSOs typically memorialize their specific intentions when RAND commitments are made. Moreover, it is questionable whether many of the patent owners making RAND commitments actually have specific intentions regarding the royalty rates that they intend to charge after the standard is adopted, as many contingencies and uncertainties surround every new standard and unproven technology. To make matters worse, it is not even clear whose intentions should be assessed when seeking to pinpoint the meaning of a patent owner's RAND commitment: the firm making the commitment, potential licensees, the SSO entity, other SSO members, or the technical community as a whole?55 There are reasons to support the views of each of these potential interpreters of "reasonable." Finally, it has become painfully apparent that when asked after the fact (e.g., when a dispute arises), each of these parties will claim intentions and recollections that are wildly at odds with one another, whether through opportunism or genuine disagreement. ${ }^{56}$ Thus, seeking to discern the intentions that parties may have had when a RAND commitment was made may be seeking to know the unknowable.

Nevertheless, disputes regarding RAND commitments arise and must be adjudicated. A key issue in such disputes is often whether, and to what degree, a patent holder has violated its commitment to offer or grant a license on RAND terms. Given the difficulty of discerning a party's actual intentions regarding the meaning of a RAND commitment at the time it was made, courts adjudicating this issue have had no choice but to apply extrinsic factors to place some meaning on the term "reasonable," if nothing else to determine whether the patent holder has breached its commitment.

\section{B. INCREMENTAL VALUE}

Incremental value is the contribution of a patented technology to the value of a product that employs the technology. Economists who have

55. See, e.g., Anne Layne-Farrar, Business Models and the Standard Setting Process, in KonkuRrensverket [SWEDish COMPETITION AuTHORITY], THE Pros AND CONS OF STANDARD SETTING 34 (2010), available at http://www.konkurrensverket.se/ globalassets/english/publications-and-decisions/the-pros-and-cons-of-standardsetting.pdf.

56. See Microsoft Corp. v. Motorola, Inc., No. C10-1823, 2013 WL 2111217 (W.D. Wash. Apr. 25, 2013) (noting that parties' initial assessments of "reasonable" royalties on two common technology standards differed by approximately a factor of 1000). 
studied standard setting often distinguish between "ex ante" and "ex post" patent values. ${ }^{57}$ The ex ante value is the anticipated contribution of a patent to the standard before the standard has been issued and firms and consumers have made irreversible commitments. The ex post value is the value of the patent after irreversible commitments have been made.

Ex post, a patent owner may be able to charge royalties that reflect the cost of switching to an alternative technology, which may be very high. Suppose a technology included in the $802.11 \mathrm{Wi}$-Fi standard is patented. Absent a RAND commitment, the patent owner may be able to charge a very high royalty for that patent because the 802.11 standard (and its modifications) are embedded in millions of devices and switching to an alternative technology would be enormously expensive and perhaps infeasible. The situation in which a firm or consumer has made irreversible commitments with high switching costs to an alternative is often referred to as "lock-in." 58

Many economists assert that a patent owner who makes a RAND commitment should not be permitted to gain the benefit of the costs of switching to an alternative standard after the standard has been adopted in the marketplace. Instead, they argue that the patent owner should be entitled to no more than the "incremental value" of the patented technology relative to its next-best alternative, measured before the standard has been adopted. ${ }^{59}$ The incremental value is the marginal contribution of the patent to the value of the product. As such, it measures the additional value that consumers obtain from the patented technology or the reduction in production costs made possible by the patented technology.

The incremental value approach first identifies the alternative technology with the highest net value: the value of the technology less its royalty cost if the technology is patented (and the royalty cost is known). Suppose a patent covers a single discrete technology, for example, a way to manage power consumption in a mobile device, and suppose there are

57. See, e.g., Gilbert, supra note 8, at 862; Farrell et al., supra note 8, at 607-08.

58. See, e.g., Farrell et al., supra note 8, at 612, 650; Miller, supra note 8, at 357.

59. See, e.g., The SEDONA CONFERENCE WORKING GRP., COMMENTARY ON PATENT DAMAGES AND REMEDIES 23 (2014), available at https://thesedonaconference .org/download-pub/3827 ("Common sense and economics both argue that, in general, it would be irrational for an accused infringer to pay more for a license to a patent than the total economic cost it would incur to implement its next best available alternative to the patented technology, inclusive of all of the costs associated with the implementation of that next best alternative."); Farrell et al., supra note 9, at 642; Gilbert, supra note 8, at 862; Lemley \& Shapiro, supra note 9, at 2041-42. 
alternative ways to manage power consumption. The ex ante incremental value of the patent is its value less the net value of the next-best alternative. Suppose the next-best alternative has a value of $\$ 0.20$ per mobile device and can be licensed at a price of $\$ 0.05$ per device. Its net value is $\$ 0.15$. Furthermore, suppose the patented technology at issue would have a value of $\$ 0.25$ per mobile device. Then the ex ante incremental value of the patent is $\$ 0.10$ per mobile device.

If alternative technologies deliver similar values, the incremental value test reduces to a comparison between the cost of the technology and the cost of the least-expensive alternative. Suppose two technologies have the same functionality. One costs $\$ 0.10$ per covered device to implement and the other costs $\$ 0.15$ per covered device. The incremental value of the first technology is $\$ 0.05$. Incremental value cannot exceed the incremental cost of the chosen technology plus any differential benefits provided by the chosen technology relative to the next-best alternative. For an ex ante calculation, the incremental cost excludes the cost of switching to the alternative technology that is a consequence of investments that are specific to the chosen technology. In the previous example, suppose either technology choice requires an upfront and non-recoverable investment of $\$ 10$ million in addition to device costs. This $\$ 10$ million cost would be excluded from an ex ante comparison of the incremental costs of the two alternatives.

The incremental value approach is admittedly difficult to implement. Technology values may be unknown or measured with too little precision to provide a reliable measure of incremental value..$^{60}$ Furthermore, as shown in the illustrative example, when alternative technologies are proprietary, the incremental value of a technology depends on the royalty payment that would be required for its alternative. This royalty may be unknown or could change in a hypothetical rivalry between alternative technologies for adoption by the SSO. ${ }^{61}$

60. Microsoft Corp., v. Motorola, Inc., No. C10-1823JLR, 2013 WL 2111217, at *13 (W.D. Wash. Apr. 25, 2013) (noting the difficulty of determining the incremental value of patents).

61. Some have argued that royalty costs should be excluded from considerations of social value because they are transfers between patent owners and patentees. See, e.g., David J. Teece \& Edward F. Sherry, Standards Setting and Antitrust, 87 MinN. L. REV. 1913, 1931-34 (2003). However, royalty costs can impede the utilization of technologies and offset performance benefits. See Mark R. Patterson, Antitrust and the Costs of Standard-Setting: A Commentary on Teece $छ$ Sherry, 87 MinN. L. REV. 1995, 1999-2003 (2003). 
Often, many patents have claims that cover a single technology. A typical standard in the information and communications technology sector can have hundreds or even thousands of patents that are declared essential to the standard. When many patents are essential to make, use, or sell products that employ a technology, the incremental value calculation does not address the value of an individual patent because each patent has a claim to the entire value of the technology. The solution to this problem requires an apportionment of the technology value to the individual patents.

Some have identified apportionment as a fatal flaw in the incremental value approach to RAND royalties. ${ }^{62}$ We disagree. Although there is as yet no single approach to apportionment that is generally accepted as ideal for every circumstance, there are guiding principles. The incremental value calculation should be performed at the level of the smallest functional unit covered by the patents at issue for which an independent value can be calculated. ${ }^{63}$ The difficulty of apportioning the value of a technology to the different patents that are necessary to make, sell, or use products that employ the technology is not unique to SEPs. It is a problem for any technology when different entities own or control patents with claims on the technology.

We do not underestimate the analytical obstacles to quantifying the incremental value of a patented technology. In some cases the incremental value may be estimated by identifying the value of the patented technology relative to an unpatented alternative, as measured, for example, by the incremental value of enhanced performance or reliability. In other cases, the incremental value may be bounded by the known cost of an alternative that is a close substitute for the patented technology. The incremental value of a technology may depend on its use. For example, the value of a $3 \mathrm{G}$ cellular technology for a mobile handset may differ from the value of

62. See, e.g., Sidak, supra note 8, at 932 (arguing that one cannot apply the "incremental value rule" when standard-essential patents must be used in fixed proportions).

63. "[W] $[$ here the entire value of a machine as a marketable article is properly and legally attributable to the patented feature, the damages owed to the patentee may be calculated by reference to that value. Where it is not, however, courts must insist on a more realistic starting point for the royalty calculations by juries-often, the smallest salable unit and, at times, even less." Ericsson, Inc. v. D-Link Sys., Inc., 773 F.3d 1201, 1227 (Fed. Cir. 2014) (citations omitted); see also VirnetX, Inc. v. Cisco Sys., Inc., 767 F.3d 1308, 1327 (Fed. Cir. 2014) (stating that the smallest saleable unit in royalty apportionment analysis need not be the smallest unit actually sold on the market: "the smallest salable unit approach was intended to produce a royalty base much more closely tied to the claimed invention than the entire market value of the accused products"). 
the technology when used in a base station, suggesting that RAND royalties may depend on the products that employ the technologies. Furthermore, implementers may value technologies differently even for the same product, and these values may depend on the competitive characteristics of markets in which the licensed technologies are used.

Anne Layne-Farrar and Gerard Llobet argue that these considerations imply that calculating incremental values can be complex and that equating royalties to incremental values may not result in socially optimal technology adoption decisions. ${ }^{64} \mathrm{We}$ agree with their first point. The latter argument is not unique to standard-essential patents and is not a reason to avoid incremental value as a basis for calculating RAND royalties. Technology adoption decisions can be inefficient for many reasons, regardless of whether the technologies have RAND licensing commitments. These market imperfections do not justify the substitution of special factors for the determination of RAND royalties that do not reflect the incremental value of the patent.

\section{BARgAining AFter STANDARD ADOPTION}

Another interpretation is that a RAND royalty rate is whatever emerges from bilateral bargaining between a willing licensor and a willing licensee ex post, after a standard has been adopted. ${ }^{65}$ Standard-related hold-up (or hold-out) may limit the comparability of negotiated licenses and restrict the set of bargaining outcomes that are relevant to a RAND determination. In Microsoft Corp. v. Motorola, Inc., Judge Robart opined that construction of a hypothetical negotiation in the RAND context must "consider alternatives that could have been written into the standard instead of the patented technology" with a focus "on the period before the standard was adopted and implemented (i.e., ex ante)." ${ }^{66}$

J. Gregory Sidak argues that a RAND royalty is the result of a bargain with a range of outcomes in which the lower bound is the minimum amount the SEP holder is willing to accept and the upper bound is the

64. See Anne Layne-Farrar \& Gerard Llobet, Moving Beyond Simple Examples: Assessing the Incremental Value Rule Within Standards, 36 INT'L J. INDUS. ORG. 57, 66 (2014) (concluding, after analysis of several negotiation scenarios, that "the hope for a formulaic incremental value calculation strikes us as unrealistic").

65. See Jorge L. Contreras, Fixing FRAND: A Pseudo-Pool Approach to StandardsBased Patent Licensing, 79 ANTITRUST L.J. 47, 55-57 (2013) (discussing "bilateralism" approach).

66. Microsoft Corp. v. Motorola, Inc., No. C10-1823JLR, 2013 WL 2111217, at *13 (W.D. Wash. Apr. 25, 2013). 
maximum amount the licensee is willing to pay. ${ }^{67}$ Of course this range applies to any negotiation, and the relevant question is how the upper and lower bounds are determined and how tightly they constrain the possible outcomes. Sidak concludes,

A royalty is FRAND if it (1) ensures the SEP holder's continued participation in standard setting, (2) does not deny the implementer access to the standard, (3) is consistent with a reasonable aggregate royalty burden for all SEPs on the implementer's standard-compliant product, and (4) approximates the royalty rates of similarly situated licenses. ${ }^{68}$

Sidak's conclusion, however, is circular in that it defines a FRAND royalty as reasonable if it is consistent with a reasonable royalty burden, without defining what is or is not reasonable. Furthermore, if one accepts our central thesis that similar principles should apply to determine reasonable royalties for SEPs and non-SEPs, then the concern with continued participation in standard setting would be substantially attenuated. Damages for infringement would be similar with or without the RAND commitment and the RAND commitment would not substantially discourage participation in standard setting.

\section{INCENTIVES FOR INVENTION}

Another approach to the determination of a RAND royalty is the financial return required to compensate the patentee for the effort and expense involved in creating the patented technology. Compensation is relevant if the RAND commitment is interpreted as a contract that explicitly requires a measure of adequate compensation. However, if SSOs do not condition the RAND commitment on a measure of adequate compensation or if compensation is not adequately defined, it is our view that a RAND commitment does not require a return from licensing that is sufficient to compensate the patentee for the cost of its invention.

The contribution from an invention is its value relative to the net value of the next-best alternative, as this measures the maximum amount that a consumer or implementer would be willing to pay for the invention. ${ }^{69}$ The incremental value of a SEP (or a technology for which many SEPs are essential) can be very small if there is an alternative available at low cost that provides similar performance. In that case, the incremental value

67. Sidak, supra note 8 , at 933.

68. Id.

69. See Gilbert, supra note 8, at 862; NAS REPORT, supra note 10, at 61-63; Farrell et al., supra note 9, at 642; Lemley \& Shapiro, supra note 9, at 2041-42. 
approach to RAND may fail to compensate the inventor for the costs involved in developing the patented technology. But that can also be true for non-SEPs and indeed for every economic activity. There is no guarantee that the marketplace will offer a price that covers the cost of supplying a product, either in the short term or ever. This does not mean that ex ante incremental value necessarily will provide the right incentive for investment to create the technologies in the first place. However, whatever distortions may occur, they should not be different merely because the selection of the technology takes place in the context of developing a standard.

In this Article, we consider how courts have approached the determination of reasonable royalties for SEPs and non-SEPs that are valid and infringed. We find that these two approaches to compensate a patent owner for infringement share more similarities than they have been given credit for, and that a royalty rate satisfying a RAND commitment should be the same as a reasonable royalty calculated for damages purposes for a non-SEP that is valid and infringed if the SEP and non-SEP have similar economic characteristics. We propose a modification to the current reasonable royalty analysis for patent damages that brings it closer to theoretical models that have been proposed to compute RAND royalty rates. Based on our consideration of alternative approaches to determine the contours of a reasonable royalty, our proposed modification emphasizes a determination of the incremental value contributed by the patented technology, evaluated before consumers or firms make investments that are specific to the patented technology.

\section{THE LAW OF PATENT DAMAGES IN THE U.S.}

There was a substantial body of law devoted to determining "reasonable" patent royalties long before the advent of RAND commitments: the law of patent damages. Patent damages are intended to make a patent holder whole with respect to an infringement. ${ }^{70}$ Damages are ex post remedies that, by definition, are only assessed after an infringement has occurred and the patents at issue have been found to be valid and enforceable. In many cases, patent damages, like damages in other tort actions, are retrospective, compensating the injured party, the patent owner, for a past harm.

70. See 7 Donald S. Chisum, Chisum On PATENTS \$20.01 (2015) ("The goal of the law of monetary relief for patent infringement is to provide full compensation to the owner of a patent."). 
But patent cases differ from most other tort cases in that the wrong committed by the infringer is not always abated going forward. That is, the infringer may be permitted by the court to continue its infringement if an injunction is not awarded..$^{71}$ Prior to the Supreme Court's 2006 decision in eBay, permanent injunctions almost always issued in patent cases following a judgment of infringement. ${ }^{72}$ But, as discussed above, the eBay four-factor test has made the issuance of an injunction in patent cases far from certain. Thus, in many instances infringement is permitted to continue indefinitely, subject only to the infringer's payment of an ongoing royalty to the patent holder. ${ }^{73}$

There are several measures by which damages in patent suits may be assessed. Lost profits may be awarded to a patent holder if sales by the infringer can be shown to have supplanted the patent holder's own sales, and courts have a wide range of latitude to impose additional damages in exceptional cases. ${ }^{74}$ But the most common measure of damages in patent cases today, and the exclusive measure of damages for post-judgment infringement (i.e., absent an injunction preventing future infringement), is a "reasonable royalty" attributable to the infringed patent. ${ }^{75}$ Below we discuss in some detail the historical development of the reasonable royalty test for patent damages, and the methodologies that have arisen to compute reasonable royalties.

71. See supra Part II (discussing the test for issuing injunctions in patent cases).

72. See, e.g., Richardson v. Suzuki Motor Co., 868 F.2d 1226, 1246-47 (Fed. Cir. 1989), cert. denied, 493 U.S. 853 (1989) ("Infringement having been established, it is contrary to the laws of property, of which the patent law partakes, to deny the patentee's right to exclude others from use of his property.... It is the general rule that an injunction will issue when infringement has been adjudged, absent a sound reason for denying it."); see also 7 CHISUM, supra note 70 \$20.04[2][a] (2014) (discussing court decisions prior to $e$ Bay).

73. Some have compared the scenario in which a permanent injunction is not granted after infringement is found to a court-ordered compulsory license. See, e.g., Paice LLC v. Toyota Motor Corp., 504 F.3d 1293, 1314 (Fed. Cir. 2007) (discussing courts' authority to order payment of royalties following denial of injunctive relief "styled a 'compulsory license' by the court" (citing Shatterproof Glass Corp. v. Libbey-Owens Ford Co., 758 F.2d 613, 628 (Fed. Cir. 1985))).

74. See 7 CHISUM, supra note 70, §§ 20.03[4][b] (Increased Damages) and 20.05 (Lost Profits).

75. See Paice, 504 F.3d at 1315 (Should the parties fail to agree upon an ongoing royalty following the denial of an injunction, "the district court could step in to assess a reasonable royalty in light of the ongoing infringement."). 


\section{A. Historical Development of Law of Patent Damages}

\section{Early History - The Need to Prove Actual Losses}

The law of patent damages developed prior to the twentieth-century merger of the courts of equity and law in the United States. ${ }^{76}$ Historically, patent holders were permitted to plead actions for infringement both in equity and at law. Today we are most familiar with the equitable remedy of injunctive relief in patent cases, but monetary damages were also available via the equitable remedy of accounting. ${ }^{77}$ Monetary recoveries at equity were based on a theory of disgorging the infringer's wrongful gains attributable to his infringement. ${ }^{78}$ In other words, a patent holder was entitled to recover from the infringer those profits that were wrongfully appropriated under a theory grounded in unjust enrichment. ${ }^{79}$ Damages for profits arising from the infringement were codified in the Patent Act of $1870 .{ }^{80} \mathrm{In}$ addition, in an action at law, a patent holder could recover from an infringer damages representing his or her own pecuniary loss resulting from the infringement, whether or not the infringer profited by the infringement. ${ }^{81}$ Thus, if the patent holder engaged in a regular program of licensing its patent to others at a certain royalty, and the infringer neglected to enter into a license agreement and pay the required royalty, the patent owner would be deemed to have lost the amount of that royalty and could collect the missing royalties as damages.

Based on these two principles, courts in the nineteenth and early twentieth centuries often reasoned that absent proof of wrongful profits earned by the infringer, or a regular program of licensing by the patent holder, the patent holder could recover only nominal damages for infringement (in addition to an injunction in equity, of course). ${ }^{82}$ The

76. The separation of courts of equity and law derives from the ancient English judicial system, in which courts of law existed separately from, and served different purposes than, the equitable courts of chancery. See generally MORTON J. HORWITZ, THE TRANSFORMATION OF AMERICAN LAW: 1780-1860, at 265-66 (Stanley N. Katz ed., 1977).

77. See 7 CHISUM, supra 70, § 20.02[1][d].

78. Coupe v. Royer, 155 U.S. 565, 582 (1895).

79. Note that this early formulation of "lost profits" damages was based on profits wrongfully earned by the infringer, consistent with the equitable action for an accounting. In the 1946 Act, by contrast, lost profits damages were defined as the profits that the patent holder would have made but for the infringer's wrongdoing, bringing them closer to a remedy at law (i.e., measured not by the infringer's undeserved gain, but the patent holder's loss). See 7 CHISUM, supra 70, \$20.02[4].

80. Patent Act of 1870, ch. 230, §55, 16 Stat. 198, 206 (enacted July 8, 1870).

81. Coupe, 155 U.S. at 582; see 7 CHISUM, supra 70, § 20.02[2].

82. Coupe, 155 U.S. at 583. 
Supreme Court's 1895 decision in Coupe v. Royer exemplified this approach. In Coupe, the holder of a patent covering a machine for converting raw hides to leather obtained a jury verdict of $\$ 18,000$ against a competitor who had used an infringing machine to process 66,000 hides. The Supreme Court reversed the verdict on the ground that no evidence had been presented regarding the patent holder's actual loss from the infringement. ${ }^{83}$ The Court held that in view of "the evidence disclosing the existence of no license fee, no impairment of the plaintiffs' market, in short, no damages of any kind, we think the court should have instructed the jury, if they found for the plaintiffs at all, to find nominal damages only." ${ }^{4}$

\section{The Emergence of Reasonable Royalty Damages}

Despite the rule against awarding patent damages absent proof of actual losses, several courts, both before and after Coupe v. Royer, did indeed award damages when lost profits and actual losses could not be shown. In these cases, courts hinted that damages based on the incremental value of the patented technology represented a fair measure of patent damages. ${ }^{85}$ In 1865 in Suffolk Co. v. Hayden, the Supreme Court held that,

There being no established patent or license fee in the case, in order to get at a fair measure of damages, or even an approximation to it, general evidence must necessarily be resorted to. And what evidence could be more appropriate and pertinent than that of the utility and advantage of the invention over the old modes or devices that had been used for working out similar results? ${ }^{86}$

In 1872, the Court in Mowry v. Whitney reversed a lower court's denial of lost profits damages arising from a patent covering an improvement in the method of making railway wheels. ${ }^{87}$ The lower court awarded the patent holder damages based on the infringer's entire profit from the sale of wheels made using the patented process, rather than only the profit

83. Id.

84. Id.; see also Rude v. Westcott, 130 U.S. 152, 167 (1889) (holding that "conjectural estimates" of patents' value did not provide adequate basis for damages finding).

85. See John C. Jarosz \& Michael J. Chapman, The Hypothetical Negotiation and Reasonable Royalty Damages: The Tail Wagging the Dog, 16 STAN. TeCH. L. REV. 769, 776-77 (2013).

86. 70 U.S. $315,320(1865)$.

87. 81 U.S. 620 (1871). 
attributable to the patented reheating and cooling process. The Supreme Court reversed, holding that,

The question to be determined in this case is, what advantage did the defendant derive from using the complainant's invention over what he had in using other processes then open to the public and adequate to enable him to obtain an equally beneficial result. ${ }^{88}$

While the Supreme Court's 1895 decision in Coupe seemingly solidified the presumption against awarding patent damages when the patentee could not prove actual losses, this presumption was toppled in 1915 with the Court's decision in Dowagiac Manufacturing Co. v. Minnesota Moline Plow Co. ${ }^{89}$ In Dowagiac, the patent covered a new design for an agricultural grain drill. Because the market for grain drills was crowded and competitive, the patent owner could not prove that the infringer's profits were elevated on account of using the patented design (i.e., that the infringer sold more drills, or that the patent holder sold fewer, on account of the infringer's use of the patented improvement). ${ }^{90}$ Likewise, the patent owner had not embarked on a licensing program for the patent, choosing instead to retain its invention as "a close monopoly." As a result, the lower court awarded the patent holder only nominal damages for the infringement. ${ }^{92}$ The Supreme Court reversed, holding that absent evidence of lost profits or an established royalty, infringement damages could still be awarded on the basis of a "reasonable" royalty. ${ }^{93}$ And even though the plaintiff could produce no direct evidence of comparable royalties charged in the market for its invention, a reasonable royalty could be computed based on "the nature of the invention, its utility

88. Id. at 651 .

89. Dowagiac Mfg. Co. v. Minn. Moline Plow Co., 235 U.S. 641 (1915). Prior to Dowagiac, some lower courts had already indicated a willingness to award "reasonable royalty" damages absent a showing of actual losses by the patentee. See U.S. Frumentum Co. v. Lauhoff, 216 F. 610, 614-17 (6th Cir. 1914) ("This damage or compensation is not, in precise terminology, a royalty at all, but it is frequently spoken of as a 'reasonable royalty; and this phrase is a convenient means of naming this particular kind of damage."); see also Oskar Liivak, When Nominal is Reasonable: Damages for the Unpracticed Patent 40-48 (Sept. 9, 2014) (unpublished manuscript), available at http://papers.ssrn.com/sol3/papers.cfm?abstract_id=2488690 (discussing lower court cases).

90. Dowagiac, 235 U.S. at 648.

91. Id.

92. Id.

93. Id. 
and advantages, and the extent of the use involved." ${ }^{4}$ The Dowagiac analysis thus takes into account the intrinsic value of the patented invention and the extent of the infringing use, rather than only demonstrable monetary losses.

The 1922 amendments to the Patent Act ${ }^{95}$ codified Dowagiac's reasoning and expressly authorized courts to award patentees a "reasonable sum" or "general damages" if a more precise measure of damages, such as existing royalty rates and lost profits, were not available. In 1946 the Patent Act was amended again, ${ }^{96}$ this time to make reasonable royalty damages explicitly available in all cases, not only those in which lost profits and existing royalty rates could not be discerned..$^{97}$ The 1952 Act, ${ }^{98}$ which largely remains in effect today, ${ }^{99}$ provides that "[u]pon finding for the claimant the court shall award the claimant damages adequate to compensate for the infringement, but in no event less than a reasonable royalty for the use made of the invention by the infringer, together with interest and costs as fixed by the court." ${ }^{100}$

The reasonable royalty measure of damages is thus available to any patentee, and forms a floor on royalties, even when the patentee cannot show lost profits. ${ }^{101}$ In addition, a reasonable royalty is the only practical measure of damages for prospective licensing of a patent after a finding of infringement (i.e., when no injunction issues). ${ }^{102}$

Following the Supreme Court's decision in Dowagiac, courts began to calculate reasonable royalty damages based on "the nature of the invention, its utility and advantages, and the extent of the use involved." 103 To a large degree, these analyses turned on discerning the value of the patented technology over available non-infringing substitutes. ${ }^{104}$ For example, the

94. Id.

95. Act of Feb. 18, 1922, Pub. L. No. 67-147, § 8, 42 Stat. 389, 392.

96. Act of Aug. 1, 1946, Pub. L. No. 79-587, 60 Stat. 778.

97. The 1946 Act also eliminated as a measure of damages the infringer's profits, thus shifting patent damages away from the equitable accounting measure toward a lawbased damages calculation. See supra note 75 .

98. Act of July 19, 1952, Pub. L. No. 82-593, 66 Stat. 812.

99. The 2011 amendments to the Patent Act, known as the America Invents Act or AIA, did not modify the damages provisions discussed herein.

100. 35 U.S.C. $\$ 284$ (2012).

101. Rite-Hite Corp. v. Kelley Co., 56 F.3d 1538, 1554 (Fed. Cir. 1995) (en banc) ("A patentee is entitled to no less than a reasonable royalty on an infringer's sales for which the patentee has not established entitlement to lost profits.").

102. See supra note 75 and accompanying text.

103. Dowagiac Mfg. Co. v. Minn. Moline Plow Co., 235 U.S. 641, 648 (1915).

104. See Seaman, supra note 28 , at $1672-73$ (discussing and citing numerous cases involving non-infringing substitutes before Georgia-Pacific). 
district court in Activated Sludge, Inc. v. Sanitary District of Chicago extensively analyzed the technical advantages of a patented sludge purification process over available alternatives. ${ }^{105}$ The court concluded that the patented process was, indeed, superior to any potential substitute, a determination that should necessarily factor into the patent holder's damages for infringement. These opinions reinforce the value-based evaluation of patent damages in Dowagiac.

\section{Georgia-Pacific and the Hypothetical Negotiation}

Throughout the mid-twentieth century, federal courts adjudicated reasonable royalty damages cases based on the intrinsic value of the infringed patents. In 1970, however, the federal court for the Southern District of New York diverged from this path in Georgia-Pacific and developed a list of fifteen factors relevant to patent royalty damages calculations. ${ }^{106}$ In Georgia-Pacific, the court held that the reasonable royalty owed to a patent holder should be determined based on consideration of the following fifteen different factors:

1. The royalties received by the patent holder for licensing the patent, proving or tending to prove an established royalty.

2. The rates paid by the licensee for the use of other similar patents.

3. The nature and scope of the license, whether it is exclusive or nonexclusive, or restricted or non-restricted in terms of territory or customers.

4. The patent holder's established policy of maintaining its patent monopoly by licensing the use of the invention only under special conditions designed to preserve the monopoly.

5. The commercial relationship between the patent holder and licensees, such as whether they are competitors in the same territory in the same line of business or whether they are inventor and promoter.

6. The effect of selling the patented article in promoting sales of other products of the licensee; the existing value

105. 64 F. Supp. 25 (N.D. Ill. 1946).

106. Georgia-Pacific Corp. v. U.S. Plywood Corp., 318 F. Supp. 1116, 1120 (S.D.N.Y. 1970), modified and affd, 446 F.2d 295 (2d Cir. 1971). For a detailed discussion of the facts and procedural history of Georgia-Pacific, see Seaman, supra note 28 , at 1681-88, and Jarosz \& Chapman, supra note 85, at 779-82. 
of the invention to the patent holder as a generator of sales of non-patented items; and the extent of such derivative or "convoyed" sales.

7. The duration of the patent and the term of the license.

8. The established profitability of the patented product, its commercial success and its current popularity.

9. The utility and advantages of the patented technology over any old modes or devices that had been used for achieving similar results.

10. The nature of the patented invention, its character in the commercial embodiment owned and produced by the licensor, and the benefits to those who used it.

11. The extent to which the infringer used the invention and any evidence probative of the value of that use.

12. The portion of the profit or selling price that is customary in the particular business or in comparable businesses.

13. The portion of the realizable profit that should be credited to the invention as distinguished from any nonpatented elements, manufacturing process, business risks or significant features or improvements added by the infringer.

14. The opinion testimony of qualified experts.

15. The amount that the patent holder and a licensee would have agreed upon at the time the infringement began if they had reasonably and voluntarily tried to reach an agreement. ${ }^{107}$

These factors represent a broad spectrum of considerations relating to the patent holder's and the infringer's potential gains from the patented technology. Factor 1 (royalties) evokes the "established royalty" test of Coupe v. Royer, while Factor 9 (utility and advantages of the patented technology) harkens back to the incremental value analysis of Dowagiac. Some factors, such as Factor 14 (expert opinions), are cumulative in that their weight goes to issues addressed in the other factors. Nevertheless, the Georgia-Pacific factor that has come to dominate the reasonable royalty analysis is Factor 15, the royalty that the parties would have agreed upon at the time the infringement began if they had reasonably and voluntarily

107. Georgia-Pacific, 318 F. Supp. at 1120 . 
tried to reach an agreement: the so-called "hypothetical negotiation" test. ${ }^{108}$ As explained by one federal district court: "Despite the fact that this hypothetical negotiation factor is just one of the factors on the list, the hypothetical negotiation is a method for incorporating the other factors in order to arrive at a reasonable royalty rate." 109 That is, in a typical GeorgiaPacific analysis, the court will apply the first fourteen factors within a framework of assessing what the parties are likely to have agreed in their hypothetical negotiation.

Over the years, the Georgia-Pacific approach has become the de facto standard for adjudicating patent royalty damages in the federal courts despite its apparent limitations. ${ }^{110}$ As recently noted by the Federal Circuit,

Although we have never described the Georgia-Pacific factors as a talisman for royalty rate calculations, district courts regularly turn to this 15-factor list when fashioning their jury instructions. Indeed, courts often parrot all 15 factors to the jury, even if some of those factors clearly are not relevant to the case at hand. And, often, damages experts resort to the factors... with little explanation as to why they do so, and little reference to the facts of record. ${ }^{111}$

In particular, the hypothetical negotiation test alluded to in Factor 15 of Georgia-Pacific has been criticized on numerous fronts. Daralyn Durie and Mark Lemley argue that the test is an obstacle to the determination of patent awards "because it overloads the jury with factors to consider that may be irrelevant, overlapping, or even contradictory." ${ }^{112}$ Other commentators have questioned the notion that such a negotiation ever would have occurred between litigants who obviously declined to enter into a license agreement and instead litigate their dispute. ${ }^{113}$ Even the

108. See, e.g., Durie \& Lemley, supra note 28, at 628-29; Jarosz \& Chapman, supra note 85, at 782-83; Seaman, supra note 28, at 1673. Though Georgia-Pacific is widely cited as the origin of the "hypothetical negotiation" test, several earlier cases adopted a similar approach. See, e.g., Seaman, supra note 28, at 1678 (citing earlier cases).

109. Studiengesellschaft Kohle mbH v. Dart Indus., Inc., 666 F. Supp. 674, 680 (D. Del. 1987).

110. See Durie \& Lemley, supra note 28 , at 628 ; Jarosz \& Chapman, supra note 85 , at 769; Seaman, supra note 28, at 1661.

111. Ericsson, Inc. v. D-Link Sys., Inc., 773 F.3d 1201, 1230 (Fed. Cir. 2014).

112. Durie \& Lemley, supra note 28 , at 628.

113. See, e.g., U.S. Fed. Trade Comm'n, The Evolving IP Marketplace: Aligning PATENT Notice AND ReMEdiEs WITH COMPETITION 170-71 (2011), available at https://www.ftc.gov/sites/default/files/documents/reports/evolving-ip-market place-aligning-patent-notice-and-remedies-competition-report-federal-trade/110307 
Federal Circuit has dismissed this scenario as "absurd."114 There is also significant concern that the opinion in Georgia-Pacific gives no practical guidance to courts or juries concerning how its fifteen factors should be weighted or compared. ${ }^{115}$ Several commentators have argued that the hypothetical negotiation test is circular, as the royalties negotiated by parties will, to a large degree, depend on the royalty rates determined by courts to be reasonable, which theoretically depend on the results of a hypothetical negotiation, and so on. ${ }^{116}$

We concur with these critiques of the Georgia-Pacific hypothetical negotiation test. The deficiencies of the Georgia-Pacific approach are made even more apparent by its inadequacy in addressing the issues raised by standard-essential patents, discussed below. Accordingly, we believe that a return to the roots of patent damages law, developed by the Supreme Court and Congress from the first Patent Act through 1970 when Georgia-Pacific was decided, is both warranted and necessary.

\section{B. RAND IN THE COURTS}

Recently, several U.S. courts have endorsed the concept that a RAND royalty should correspond to the value of the patented technology when the standard is developed and should not capture post-adoption costs required to switch to a different technology. In conducting this analysis, courts in several recent cases have attempted to apply the Georgia-Pacific

patentreport.pdf; Thomas F. Cotter, Four Principles for Calculating Reasonable Royalties in Patent Infringement Litigation, 27 SANTA CLARA COMPUTER \& HiGH TECH. L.J. 725, 730 (2011); Jarosz \& Chapman, supra note 85; Brian J. Love, The Misuse of Reasonable Royalty Damages as a Patent Infringement Deterrent, 74 MO. L. REV. 909, 914 (2009); Seaman, supra note 28, at 1660-61.

114. Rite-Hite Corp. v. Kelley Co., 56 F.3d 1538, 1554 n.13 (Fed. Cir. 1995) (en banc).

115. See Durie \& Lemley, supra note 28, at 631; John W. Schlicher, Patent Damages, the Patent Reform Act, and Better Alternatives for the Courts and Congress, 91 J. PAT. \& TRADEMARK OFF. SOC'Y 19, 22 (2009); Seaman, supra note 28, at 1704. J. Gregory Sidak attempts to add structure to the Georgia-Pacific factors by appealing to bargaining theory. J. Gregory Sidak, Bargaining Power and Patent Damages, 19 STAN. TECH. L. REV. 1 (2015). Christopher Seaman argues that reasonable royalties for patent infringement should be based on historical damages. Christopher B. Seaman, Ongoing Royalties in Patent Cases After eBay: An Empirical Assessment and Proposed Framework, 23 TEX. INTELL. PROP. L.J. 203 (2015). Neither approach accounts for factors relevant to standard-essential patents, such as the extent to which adoption of a standard makes alternative technologies more distant substitutes.

116. See, e.g., Jarosz \& Chapman, supra note 85, at 823 n.251; Suzanne Michel, Bargaining for RAND Royalties in the Shadow of Patent Remedies Law, 77 ANTITRUST L.J. 889, 897 n.34; Mark Schankerman \& Suzanne Scotchmer, Damages and Injunctions in Protecting Intellectual Property, 32 RAND J. ECON. 199, 200 (2001). 
factors to determine appropriate RAND royalty rates. ${ }^{117}$ Yet in doing so, and as described in some detail below, these courts each concluded that the Georgia-Pacific analysis is ill-suited to making RAND royalty determinations.

In Microsoft v. Motorola, Judge James Robart of the Federal District Court for the Western District of Washington sought to determine both a reasonable royalty and a range of reasonable royalties for Motorola's patents covering two industry standards (ITU's H.264 audiovisual compression standard and IEEE's 802.11 wireless networking standards). ${ }^{118}$ In doing so, Judge Robart looked first to the reasonable royalty damages analysis in Georgia-Pacific, including its hypothetical negotiation framework. ${ }^{119} \mathrm{He}$ reasoned that the parties to a hypothetical negotiation would set RAND royalty rates by "looking at the importance of the SEPs to the standard and the importance of the standard and the SEPs to the products at issue." ${ }^{120}$ However, the court also noted that "[f]rom an economic perspective, a RAND commitment should be interpreted to limit a patent holder to a reasonable royalty on the economic value of its patented technology itself, apart from the value associated with incorporation of the patented technology into the standard." 121

The court determined RAND royalties for Motorola's patents by adopting a modified version of the Georgia-Pacific factors to recreate a hypothetical negotiation between the parties. The court expressly modified twelve of these factors. The modifications generally address,

(i) The lack of comparability of negotiated royalty terms that fail to account for RAND obligations. (Factors 1 and 12$)^{122}$

(ii) The importance of the value of the patented technology apart from the value associated with incorporation of the

117. See Microsoft Corp. v. Motorola, Inc., No. C10-1823JLR, 2013 WL 2111217, at *16-17 (W.D. Wash. Apr. 25, 2013); In re Innovatio IP Ventures, LLC Patent Litig., 921 F. Supp. 2d 903, 907 (N.D. Ill. 2013); Ericsson, Inc. v. D-Link Sys., Inc., 773 F.3d 1201, 1229-30 (Fed. Cir. 2014).

118. Microsoft, No. C10-1823JLR, 2013 WL 2111217, at *1-4.

119. Id. at *19; see also Kassandra Maldonado, Breaching RAND and Reaching for Reasonable: Microsoft v. Motorola and Standard-Essential Patent Litigation, 29 BERKELEY TECH. L.J. 419, 443-46 (summarizing the court's adaptation of the GeorgiaPacific factors).

120. Microsoft, 2013 WL 2111217, at *3.

121. Id. at $* 18$.

122. Id. at ${ }^{*} 18-19$ 
patented technology into the standard. (Factors 6, 8, 10, 11 , and 13$)^{123}$

(iii) The importance of alternatives that could have been written into the standard instead of the patented technology, with the focus on the period before the standard was adopted and implemented. (Factor 9) ${ }^{124}$

(iv) The purpose of the RAND commitment to encourage widespread adoption of the standard through avoidance of hold-up and stacking. (Factor 15) 125

(v) The irrelevance of some of the factors because they do not relate to the RAND context (e.g., whether patentee has a policy to license others, relationship of the licensor and licensee, and the patent term). (Factors 4, 5, and $7)^{126}$

It is useful to consider whether Judge Robart's modifications to the Georgia-Pacific factors are dictated specifically and uniquely by the presence of a RAND commitment. We conclude that they are not. Any licensing commitment-for example, a commitment to license at a particular level in the supply chain for a product-would raise similar comparability issues and may exclude some of the Georgia-Pacific factors from consideration. Consider Judge Robart's modifications to Factors 6, 8, $10,11,13$, and 15 , which focus on the importance of the value of the patented technology apart from the value associated with incorporation of the patented technology into the standard. One could apply the same reasoning to a patented technology that is incorporated in any product, without regard to whether the product complies with a particular standard. A reasonable royalty for a patent should be determined by the value of the patented technology and not by the costs of switching to another technology. Alternatively, Judge Robart could be saying that the standardization context is unique; however he has offered no clear explanation to reach this conclusion.

Judge Robart's modification to the ninth Georgia-Pacific factor highlights the lack of specificity of his conclusions to the RAND licensing context. Factor 9 addresses the importance of alternatives that could have been written into the standard instead of the patented technology. Judge Robart's modification emphasizes that this evaluation must focus on the

123. Id.

124. Id. at $* 19$.

125. Id. at *20.

126. Id. at *18-19. 
period before the standard was adopted and implemented. However, he does not explain why such an ex ante limitation is warranted for the determination of a RAND royalty but not in other licensing contexts.

In In re Innovatio IP Ventures Patent Litigation, ${ }^{127}$ Judge James Holderman of the Northern District of Illinois largely followed the framework described by Judge Robart for the determination of RAND royalties. In particular, he applied a modified Georgia-Pacific analysis that simulates a hypothetical bilateral negotiation in the context of RAND obligations. ${ }^{128}$ Judge Holderman further explained,

The purpose of conducting such a hypothetical negotiation is "to ascertain the royalty upon which the parties would have agreed had they successfully negotiated an agreement just before infringement began." Accordingly, the court must try, "as best as possible, to recreate the ex ante licensing negotiation scenario and to describe the resulting agreement." 29

Most recently, in Ericsson, Inc. v. D-Link Systems, Inc., a case involving RAND-encumbered patents, the Federal Circuit reversed and remanded a jury verdict based, in part, on the district court's jury instruction to apply the fifteen Georgia-Pacific factors without modification. ${ }^{130}$ The Federal Circuit affirmed that "[i]n a case involving RAND-encumbered patents, many of the Georgia-Pacific factors simply are not relevant; many are even contrary to RAND principles." ${ }^{31}$

The Federal Circuit noted several respects in which the Georgia-Pacific factors were both irrelevant and contrary to the RAND commitment under consideration. ${ }^{132}$ Like Judge Robart in Microsoft v. Motorola, the Federal Circuit criticized the use of Georgia-Pacific Factors 4, 5, 8, 9 and 10 when considering royalties subject to a RAND commitment. ${ }^{133}$ Though the court did not hold that a modified version of the GeorgiaPacific factors must be used in cases involving SEPs, it found that the

127. In re Innovatio IP Ventures, LLC Patent Litig., 921 F. Supp. 2d 903, 915-17 (N.D. Ill. 2013).

128. See Maldonado, supra note 119, at 452-54 (summarizing the court's methodology).

129. Microsoft, 2013 WL 2111217, at *17 (citing Lucent Techs., Inc. v. Gateway, Inc., 580 F.3d 1301, 1324 (Fed. Cir. 2009)).

130. Ericsson, Inc. v. D-Link Sys., Inc., 773 F.3d 1201, 1229-30 (Fed. Cir. 2014).

131. Id. at 1230 .

132. Id. at 1230-31. For example, the court states that "factor 5-' $[t]$ he commercial relationship between the licensor and licensee'-is irrelevant because Ericsson must offer licenses at a non-discriminatory rate." Id. (quoting Georgia-Pacific Corp. v. U.S. Plywood Corp., 318 F. Supp. 1116, 1120 (S.D.N.Y. 1970)).

133. Id. 
combination of errors in the lower court's instructions to the jury was significant enough to warrant remand. ${ }^{134}$

\section{THE CASE FOR A UNIFIED FRAMEWORK FOR REASONABLE ROYALTIES}

In this Part, we argue that a reasonable royalty should take into account the ex ante alternatives to the patented technology and focus on the incremental contribution of the asserted patent to the infringing product. Regardless of whether the patent is subject to a RAND commitment, the relevant alternatives for this hypothetical negotiation are the alternatives that were available before the infringer made investments that are specific to the patented technology and, in the case of a de facto market standard, before others make investments that cause available alternatives to become distant substitutes.

With this interpretation, there is nothing "essential" about standardessential patents. A RAND commitment carries weight and is not irrelevant to the determination of a reasonable royalty. It is not seriously disputed that a RAND commitment creates an obligation to offer a license for the patented technology. ${ }^{135}$ The commitment also prohibits patent terms that are unduly discriminatory, without describing precisely the conditions under which patent terms fail the non-discrimination requirement. What the RAND commitment does not do in our opinion is create a unique approach to the evaluation of patent damages that predates investments by the infringer or others that are specific to the patented technology. We argue that the law provides a basis to conclude that a patentee should not benefit from such investments, without regard to whether the patent is burdened with a RAND commitment.

\section{A. Patent Hold-Up Is A Risk FOR Both SEPS AND NON-SEPs}

As described above, when faced with the task of estimating RAND royalties, courts have modified the Georgia-Pacific factors to stress an ex ante hypothetical negotiation to eliminate the risk of hold-up. Yet the risk of hold-up is not unique to patents with RAND commitments. For example, Carl Shapiro concludes that if courts rely on observed licensing rates to estimate a reasonable royalty for an infringed patent, the threat of hold-up can lead to royalty estimates that far exceed the social value of the

134. Id.

135. See Contreras, supra note 50, at 14 (analyzing legal theories supporting the enforcement of RAND commitments). 
patent, without regard to whether the patent is essential to a standard. ${ }^{136}$ The Federal Trade Commission, in its review of methodologies to estimate damages for patent infringement generally and not specifically limited to SEPs, recommends that "[to] prevent damage awards based on switching costs, courts should set the hypothetical negotiation at an early stage of product development, when the infringer is making design decisions and before it has sunk costs into using the patented technology."137

Judge Robart opined that a RAND commitment distinguishes the hypothetical negotiation from a circumstance in which the patentee has not made a RAND commitment in his conclusion that "a proper methodology used to determine a RAND royalty should therefore recognize and seek to mitigate the risk of patent hold-up that RAND commitments are intended to avoid." 138 The mitigation of patent hold-up is a desirable end and one that may be reinforced by a RAND commitment. But if the mitigation of patent hold-up is a desirable end, it is also a desirable end for patents that lack a RAND commitment.

The ability of a patent owner to hold up an infringing firm by demanding royalties that reflect the fact that the infringer has made investments that are specific to the patented technology is by no means unique to the context of standards. Firms often make irreversible investments when they develop a product, independent of whether the product complies with a particular standard. These irreversible investments can allow a patentee to charge higher royalties than the patentee could obtain in a hypothetical negotiation that occurs before the specific investments are made. ${ }^{139}$ Furthermore, a firm can be locked-in to the use of patented technologies that become de facto market standards. If it is a desirable end to mitigate hold-up for patents that are subject to RAND commitments, it is also desirable to mitigate hold-up for other patents. ${ }^{140}$

136. See Shapiro, supra note 14, at 309.

137. THE EVOLVING IP MARKETPLACE, supra note 113, at 22.

138. Microsoft Corp. v. Motorola, Inc., No. C10-1823JLR, 2013 WL 2111217, at *12 (W.D. Wash. Apr. 25, 2013) (emphasis added).

139. See Miller, supra note 8, at 355; Swanson \& Baumol, supra note 8, at 10-11.

140. Allowing patent owners to benefit from lock-in can deter willful infringement, that is, infringement made with full knowledge that the activity violates the patent. However, findings of willful infringement are relatively rare and courts have the discretion to award treble damages if infringement is willful, which undermines the deterrence effect of allowing patentees to benefit from investments made by the infringer. See Kimberly A. Moore, Empirical Statistics on Willful Patent Infringement, 14 FED. CIR. 
We contend that the analysis of RAND royalties conducted by Judges Robart and Holderman need not be limited to patents covered by RAND commitments. SEPs should not benefit from switching costs that arise from investments that are specific to the standard. The same logic applies to all patents. A patentee should be compensated for the value of her invention, as defined by its marginal contribution over the prior art. The patentee should not enjoy a benefit that arises merely because the infringer has made investments that have high switching costs. ${ }^{141}$

A further consideration in the evaluation of reasonable royalties for both SEPs and non-SEPs arises when, as is often the case, a product requires licenses to use many patents held by different owners. In that circumstance, each patent owner has an incentive to demand a large share of the value of the product and the resulting total royalty demand can exceed the demand that would maximize a licensor's profit if it were the sole source for all of the patents. This phenomenon is called "royaltystacking." 142 We discuss its implications below for a common framework to evaluate patent infringement damages.

\section{B. Royalty-STACKING Is Not UniQUe To SEPS}

The court in Microsoft $v$. Motorola recognized that patent damage demands could impose costs on implementers and consumers that cannot be reconciled with a desire to compensate patent owners. ${ }^{143}$ When multiple independent patent owners each demand compensation for patent infringement, the total of these royalty demands can exceed the level that would maximize their joint profits. This "royalty stacking" issue is a cause for courts to evaluate individual royalty demands in the context of the potential total royalty burden that patent owners might impose on implementers and consumers. Judge Robart noted,

Motorola's royalty request for its 802.11 SEP portfolio raises significant stacking concerns. There are at least 92 entities that own 802.11 SEPs. If each of these 92 entities sought royalties

B.J. 227, 234 (2004) (willfulness found in 2.1\% of patent cases decided in 1999-2000); Christopher B. Seaman, Willful Patent Infringement and Enhanced Damages After In Re Seagate: An Empirical Study, 97 IowA L. REV. 417, 436-37 (2012) (finding that 1.9\% of all patent cases filed between 2004 and 2010 resulted in a final merits decision on willfulness).

141. Exceptions may be justified for willful infringement, although the use of treble damages may be sufficient to deter such behavior. See sources cited supra note 140 .

142. See Jorge L. Contreras, Standards, Royalty Stacking and Collective Action, 3 CPI ANTITRUST CHRON., Mar. 2015; NAS REPORT, supra note 10, at 55-57; Lemley \& Shapiro, supra note 9, at 1993.

143. See Microsoft, 2013 WL 2111217. 
similar to Motorola's request of $1.15 \%$ to $1.73 \%$ of the endproduct price, the aggregate royalty to implement the 802.11 Standard, which is only one feature of the Xbox product, would exceed the total product price. ${ }^{144}$

Judge Robart specifically noted that "a royalty rate that implicates such clear stacking concerns cannot be a RAND royalty rate because such a royalty rate does not stand up to the central principle of the RAND commitment-widespread adoption of the standard." ${ }^{45}$ Yet concerns about royalty stacking also are relevant to the determination of a reasonable royalty for non-SEPs when patents held by many different owners cover a technology. ${ }^{146}$ Many technological fields have crowded intellectual property rights. While thousands of patents have been declared to be essential to certain popular telecommunications and networking standards, many more thousands of patents cover non-standardized components and features of modern electronic devices. One source estimates that more than 250,000 patents cover a single smartphone, far in excess of the patents that cover technical standards implemented by the device. ${ }^{147}$ In this regard, product manufacturers must deal with both SEPs

144. Id. at *73 (internal citation omitted).

145. Id.

146. See, e.g., Farrell et al., supra note 9; Lemley \& Shapiro, supra note 9; Taylor, supra note 28, at 138 ("Any assessment of reasonable royalties must correct for this potential problem [stacking] by taking into account complementary technologies and identifying relative contributions to their gross value...."); SEDONA, supra note 59, at 17 (relevant factors to consider in patent damages assessment include "(ix) royalty stacking, if any").

147. RPX Corp., Registration Statement (Form S-1) (Jan. 21, 2011), at 55 (U.S. Securities and Exchange Commission filing) ("Based on our research, we believe there are more than 250,000 active patents relevant to today's smartphones, a significant increase compared to our estimate of approximately 70,000 patents that were active and relevant to mobile phones in 2000. This growth can be attributed to the expanded set of features and functionality incorporated in today's smartphones, including touchscreens, internet access, streaming video, media playback, application store readiness and other web-based services, and WiFi connectivity options."); see also Ann Armstrong, Joseph J. Mueller \& Timothy D. Syrett, The Smartphone Royalty Stack: Surveying Royalty Demands for the Components Within Modern Smartphones (Working Paper, May 29, 2014), available at http://papers.ssrn.com/sol3/papers.cfm?abstract_id=2443848. With respect to patents covering particular standards, see KNUT BLIND ET AL., STUDY ON THE INTERPLAY BETWEEN STANDARDS AND INTELLECTUAL PROPERTY RIGHTS (IPRS), FINAL REPORT 62 (2011), available at http://ec.europa.eu/enterprise/policies/europeanstandards/files/standards_policy/ipr-workshop/ipr_study_final_report_en.pdf (reporting the numbers of patents believed to be essential to standards including WCDMA (1000 patent families), LTE (1000 patent families), MPEG-2 and MPEG-4 (800 patents in 160 patent families), optical disc drive standards (2200 patent families), and DVB-H (30 patent families)). We express no opinion about the accuracy of these estimates. Rather, 
and non-SEPs, and the reason to distinguish these two categories of patents again fades.

Similarly, the fact that a patent is declared as a SEP does not necessarily mean that the patent is, indeed, essential to implement the standard in a particular product, or that a standard-compliant product will infringe the patent. Studies have shown extensive over-declaration of patents as essential to standards. ${ }^{148}$ Courts have recently established that, notwithstanding a patent holder's declaration that its patent is essential to a standard, neither the essentiality of the patent to the standard nor the infringement of the patent by a product implementing the standard can be assumed. ${ }^{149}$ Further a defendant is entitled to argue both non-essentiality and non-infringement when the patent is asserted against it. ${ }^{150}$ In this respect as well, SEPs are no different than non-SEPs, and treating them differently in the reasonable royalty/hypothetical negotiation context is not justified.

The potential for royalty stacking is relevant to the determination of reasonable royalties in the context of both RAND commitments and patent damages more generally. In an industry characterized by multiple patents that cover component technologies of a product that implements many technologies, the incremental value of a particular patented component technology to the overall product value is likely to be lower if many other patented technologies also compete for a share of the overall product value. As a result, it is reasonable to introduce evidence regarding the number of patents and other patented technologies in the overall product when assessing the incremental value of a particular patented technology. ${ }^{151}$ Conversely, withholding evidence regarding the total field

we merely note that the large number of non-SEPs reinforces our conclusion that concerns about royalty-stacking are not unique to SEPs.

148. See generally Contreras, supra note 65, at 60-62; Rudi Bekkers, René Bongard \& Alessandro Nuvolari, An Empirical Study on the Determinants of Essential Patent Claims in Compatibility Standards, 40 RESEARCH POL'Y 1001 (2011); David J. Goodman \& Robert A. Myers, $3 G$ Cellular Standards and Patents, 2005 INT'L CONF. ON WIRELESS NETWORKS, COMM. \&MOBILE COMPUTING 415 (2005).

149. See In re Innovatio IP Ventures, LLC, 921 F. Supp. 2d 903 (N.D. Ill. 2013); Apple Inc. v. Motorola, Inc., 869 F. Supp. 2d 901, 913-14 (N.D. Ill. 2012), aff d in part, 757 F.3d 1286 (Fed. Cir. 2014).

150. Id.

151. In Ericsson, Inc. v. D-Link Systems, the Federal Circuit held that "As with all patents, the royalty rate for SEPs must be apportioned to the value of the patented invention," but also noted that "[t]he district court need not instruct the jury on hold-up or stacking unless the accused infringer presents actual evidence of hold-up or stacking." 773 F.3d 1201, 1232, 1234 (Fed. Cir. 2014). We note that this evidentiary requirement could give an undue advantage to patent holders who are among the first to assert their 
of patents covering a particular product or standard may lead a fact finder to overestimate the incremental value of the patent at issue, as knowing that a particular patent is only one of a thousand covering a product is likely to result in a different assessment of the patent's worth than believing it is the sole patent germane to the product.

\section{Timing of Hypothetical Negotiations-Converging on THE RAND ANALYSIS}

When considering the appropriate methodology for determining a reasonable royalty under the Georgia-Pacific framework, one must consider the time at which the hypothetical negotiation should be deemed to occur. Georgia-Pacific Factor 15 calls for consideration of the amount that the patent holder and a licensee would have agreed upon at the time the infringement began. ${ }^{152}$ Under the law, infringement "begins" when a party first makes, uses, or sells an infringing product. ${ }^{153}$

For a patent encumbered with a RAND commitment, Judge Robart's modification of the hypothetical negotiation in Georgia-Pacific considers the alternatives available ex ante, before the standard was adopted. With this modification, the patentee would not have leverage to exploit a firm's irreversible investments, without regard to whether the firm invested before or after a standard was adopted. Consider the following situation. There is a patent that covers a standard. Two firms make irreversible investments to supply a product that complies with the standard. Firm 1 invests immediately before the standard is formally adopted. Firm 2 invests much later after the standard has achieved wide acceptance in the market. After Firm 2 invests, the patent owner brings an infringement claim against both firms.

A hypothetical negotiation that occurs before the standard was formally adopted and implemented would consider the alternatives available before both firms invest. The available alternatives would not be diminished by investments that lock the firm into the standard. Under this hypothetical, the patentee could not "hold up" either firm by exploiting the firms' irreversible investments.

Suppose the patent at issue is not a SEP. Consider a new technology that achieves a superior signal-to-noise ratio for communications between

patents against a particular infringer. See Contreras, supra note 142, at 6 (providing a more detailed discussion of how a "race to the courthouse" phenomenon could arise).

152. Georgia-Pacific Corp. v. U.S. Plywood Corp., 318 F. Supp. 1116, 1120 (S.D.N.Y. 1970), modified and affd, 446 F.2d 295 (2d Cir. 1971).

153. 35 U.S.C. $§ 271$ (a) (2012). 
mobile phones and base stations. Either the new technology is not included in a communications standard or the technology is included in a standard but the patentee has not made a RAND commitment. Nonetheless, many sellers of mobile phones incorporate the new technology in their handsets and it has become a de facto market standard that is supported by base stations, to the exclusion of other similar technologies.

As in the previous example, Firm 1 and Firm 2 supply handsets that infringe the patent. Firm 1 is the first handset manufacturer to adopt the patented technology, while Firm 2 invests after the new technology has achieved widespread market acceptance and become a de facto communications standard. At the time that Firm 1 first infringes the patent, its technology alternatives are not limited by the practical necessity of maintaining compatibility with existing base stations. To the extent that viable alternatives are available when Firm 1 first makes sunk investments that infringe the patent, those alternatives would lower the royalty that would emerge from the hypothetical negotiation between the patent holder and Firm 1.

In contrast, Firm 2 faces the practical necessity of maintaining compatibility with the network of base stations that employ the patented technology. If Firm 2 chooses to invest, its alternatives available at the time the infringement begins are limited by the fact that the patented technology has become a de facto market standard. The patentee could exploit the lack of alternatives and charge a higher royalty to Firm 2. Following Georgia-Pacific, the hypothetical negotiation between the patent holder and Firm 2 would reflect the lack of alternatives and indicate a higher royalty compared with the hypothetical negotiation with Firm 1.

Yet there is no fundamental difference between the value contribution of the patent for the similar products supplied by Firm 1 or Firm 2. Firm 2 faces a more difficult hypothetical negotiation because other firms have chosen to support handsets and base stations that employ the patented technology. These decisions allow the patentee to negotiate a higher royalty because they limit the practical alternatives for Firm 2. They do not increase the value of the patent; rather, they make alternatives to the patented technology more distant substitutes.

The timing of the hypothetical negotiation in the Georgia-Pacific analysis addresses in part whether a patent owner can benefit from investments and other market factors that affect the available alternatives for the patented technology. If the hypothetical negotiation occurs before the implementing firm makes sunk investments, the patent owner should not be able to benefit from the high cost of switching to alternatives after 
investments have been sunk. However, actions by other market participants to support a technology also can affect the available alternatives that are relevant to a hypothetical negotiation. If the alternatives are measured before either the infringer or other market participants make investments that are specific to the patented technology, then the calculation of a compensatory royalty would mirror the ex ante value calculation for a RAND royalty.

It is our view that the hypothetical negotiation for both SEPs and non-SEPs should reflect an environment in which neither the infringer nor others have made investments that are specific to the patented technology. We propose that Judge Robart's modification of the GeorgiaPacific factors to consider a hypothetical negotiation that occurs before the standard was adopted should apply more generally to non-SEPs, if market developments severely limit the choices that are practical alternatives to the patented technology. The hypothetical negotiation should embody the intent of Judge Robart's modification to capture the ex ante value of the patented technology, rather than the costs of switching to substitutes that are made distant by market developments, even if the patent does not cover a standard-essential patent with a RAND commitment. For both SEPs and non-SEPs, the hypothetical negotiation should reflect the alternatives available to the infringer before it is locked-in to the patented technology, either by its own actions or by the actions of others. This hypothetical negotiation captures the incremental value contribution of the patent and avoids confounding that value contribution with other factors unrelated to the patented technology that limit the alternatives available to the infringer.

\section{InCONSISTENT TREATMENT OF PATENT INFRINGEMENT DAMAGES FOR SEPS AND NON-SEPS}

Several notable patent cases illustrate the inconsistent treatment of infringement damages for SEPs and non-SEPs. In some of these cases, awards exceed a reasonable approximation of the asserted patent's incremental value. ${ }^{154}$ In Lucent Technologies, Inc. v. Gateway, Inc. (Lucent I),

154. See Seaman, supra note 28, at 1663-64 (citing Lucent Techs. v. Gateway, Inc. (Lucent I), 509 F. Supp. 29912 (S.D. Cal 2007) (awarding \$1.53 billion); Saffran v. Bos. Sci. Corp., No. 2:05-CV-547, 2008 WL 2716318 (E.D. Tex. July 9, 2008) (awarding $\$ 501$ million); Cornell Univ. v. Hewlett-Packard Co., 609 F. Supp. 2 d 279 (N.D.N.Y 2009) (awarding $\$ 184$ million)). But see Brian Howard, The Truth About Patent Damage Awards, LAW360 (Oct. 16, 2014), http://www.law360.com/articles/557734/the-truthabout-patent-damage-awards (reporting that damages of less than $\$ 2.3$ million were awarded in 75\% of patent cases between 2000 and 2013). 
Lucent alleged that Microsoft's Windows Media Player and associated software infringed two of Lucent's patents for encoding audio in the MP3 format. ${ }^{155}$ The trial resulted in a jury verdict that initially awarded Lucent (and its successor, Alcatel-Lucent) $\$ 1.5$ billion for infringement of the two MP3 patents. ${ }^{156}$ Around the time of the litigation, Alcatel-Lucent was one of at least three entities that owned or licensed MP3 patents. The other two were Thompson, the licensing agent for patents owned by Fraunhofer IIS; and Audio MPEG, a subsidiary of Sisvel S.p.A., which licensed MP3 patents owned by France Telecom, Philips, and others. ${ }^{157}$

In Microsoft v. Motorola, Judge Robart concluded, "where multiple technologies (including both standard-essential and non-essential patents) are licensed within the same agreement, it is necessary to apportion the value of Motorola's 802.11 or H.264 SEPs from the other licensed properties." 158 Yet there was no mention in Lucent I of the other MP3 patents that were necessarily infringed by Microsoft's Windows Media Player.

It is also notable that the MP3 technology is an element of the MPEG-1 and MPEG-2 audio and video standards developed by the International Organization for Standardization. Lucent had not made a RAND commitment for the patents asserted in the MP3 litigation. ${ }^{159}$ Nonetheless, issues such as incremental value and apportionment, duly noted by Judge Robart as necessary to estimate a reasonable royalty for patents with RAND commitments, are also present in Lucent I. Had the Lucent I court followed the roadmap described by Judge Robart or the "incremental value" test originated in Dowagiac and focused on the contribution of the asserted patents to the value of the infringing products and took into account the many other patents covering the same standard,

155. Lucent I, 509 F. Supp. 2 d at 917.

156. Id. at 940 . The district court granted defendants judgment as a matter of law. On appeal, the Federal Circuit ruled that Lucent had no standing to sue for one of the patents and that the defendants had not infringed the other patent. Lucent Techs., Inc. v. Gateway, Inc., 543 F.3d 710, 729, 733 (Fed. Cir. 2008).

157. Fraunhofer IIS is a research laboratory that contributed to the development of digital encoding technologies.

158. Microsoft Corp. v. Motorola, Inc., No. C10-1823JLR, 2013 WL 2111217, at *69 (W.D. Wash. Apr. 25, 2013) (internal citations omitted).

159. Lucent acquired Alcatel in 2006. A related issue in the case was whether Lucent was bound by Alcatel's prior agreement with the MPEG patent pool to license its MP3 patents. The court ruled that Lucent was not bound by this agreement. See Lucent Techs., Inc. v. Gateway, Inc., No. 02-2060-B, 2007 U.S. Dist. LEXIS 73768 (S.D. Cal. Oct. 1, 2007). 
it is likely that the court or jury would have established a lower royalty level.

Judge Robart's recognition of the shared value of intellectual property rights demonstrates a degree of sophistication that is often lacking in cases that allege damages for patent infringement. At least six of the ten largest patent infringement damage awards in recent years involved technologies covered by numerous patent rights. ${ }^{160}$ The apportionment of value to individual patents should be required for all demands for infringement damages when rights to multiple patents and other tangible as well as intangible assets are necessary to make, sell, or use a product or to provide a service. Although recent litigation involving SEPs highlighted the central importance of the need to apportion value to the patents at issue, the logic of apportionment is not unique to SEPs.

It is not our view that a RAND commitment is meaningless. Rather, our view is that litigation involving patents with RAND commitments has identified critical factors-such as apportionment, incremental value, and the potential for hold-up to distort negotiations-that are potentially relevant to all patents. These factors, with appropriate weights, should be considered in all patent infringement damages calculations. The history of patent litigation provides support for this conclusion, but that support has been obscured by the unstructured and ill-defined parameters in GeorgiaPacific. A return to the roots of patent damage law would allow a consistent treatment of patents with and without RAND commitments. ${ }^{161}$

\section{E. UNIFORMITY ENCOURAGES PARTICIPATION IN STANDARD- SETTING}

Treating patent damages uniformly, as we propose, has additional benefits. Differing approaches to SEPs and non-SEPs may encourage patent owners to avoid participation in standard-setting because doing so may enable them to escape the burden of a RAND commitment. This opt-out behavior potentially incurs significant social costs. The process of

160. PricewaterhouseCoopers, 2014 Patent Litigation Study 7, chart 3 (2014).

161. In a subsequent case involving Lucent and Microsoft, Lucent Technologies, Inc. v. Gateway, Inc. (Lucent II), 580 F. Supp. 2d 1016 (S.D. Cal. 2008), vacated, 580 F.3d 1301 (Fed. Cir. 2009), the court also analyzed existing Lucent patent licenses to determine comparable royalty levels. These exemplars included licenses of both standard-essential patents, such as those covering the MPEG audiovisual compression standard, $i d$. at 1331, and non-standardized technologies such as PC graphics boards, id. at 1330. Both SEPs and non-SEPs were considered in the royalty analysis, and their status as such did not merit mention in the court's decision. 
standard setting benefits from wide participation, which is lacking if innovators choose not to participate in the development of new standards. In addition, patent hold-up by a patentee with no RAND commitment, because the patent owner opted out of standards development, has economic consequences similar to patent hold-up by a patentee that participated in the development of the standard.

Innovators will not be deterred from participating in SSOs that impose RAND commitments if, as we suggest, the royalties they can obtain when enforcing SEPs do not depend significantly on whether the patents are subject to RAND commitments. To accomplish this end, it is neither necessary nor productive to allow RAND royalties to capture the costs to firms and consumers of investments that lock themselves into a standard. A far better solution is to require infringers of SEPs to compensate patent owners based on the value of the patents relative to the alternatives available when the standard was being developed. Lock-in should not be a source of reward to patent owners, whether or not the patent is subject to a RAND licensing commitment.

Furthermore, to the extent that damages may reward patentees at levels up to the costs that infringers would incur if forced to switch to alternative technologies, patent owners would be encouraged to act strategically in their assertion of patent rights. They might thus delay the notice of infringement until firms have made substantial sunk investments or until patented technologies are so widely adopted that they become de facto standards (i.e., the classic "hold-up" scenario). ${ }^{162}$ In the context of standard-setting, owners of patents that may be essential to a standard may choose to avoid the standard-setting process and instead assert their patents as non-participants if that allows them to negotiate higher royalties. ${ }^{163}$ Yet, under our proposal, the underlying value of the patent will be unaffected by its owner's decision as to whether or not to participate in standard setting. ${ }^{164}$

162. See Farrell et al., supra note 9; Lemley \& Shapiro, supra note 9.

163. Rambus, Inc. is alleged to have taken this approach when it withdrew from an SSO in which it had participated prior to adoption of a new standard on SDRAM technology so that it could assert patents against SDRAM manufacturers adopting the standard. See Rambus Inc. v. Infineon Techs. AG, 318 F.3d 1081 (Fed. Cir. 2003).

164. Einer Elhauge argues that the same legal standards should apply to RAND commitments whether they are made to standard-setting organizations or not. Einer Elhauge, Treating RAND Commitments Neutrally, 11 J. COMPETITION L. \& ECON. 1 (2015). In contrast, we argue that the determination of a reasonable royalty for patent infringement should be based on the economic and technical characteristics of the 
A related issue is whether a RAND commitment "travels with the patent" or is limited to the party that made the pledge and its licensee. ${ }^{165}$ This question has central importance if (i) a RAND commitment requires a distinct approach to remedy patent infringement, and (ii) the commitment is limited to the patentee that made the commitment and its licensee. In that case, selling or assigning the patent to a third party easily avoids a RAND commitment. However, this issue becomes less critical if, as we argue, a RAND commitment does not require a different approach to remedy patent infringement. If, instead, the determination of "reasonable" depends on the incremental contribution of the patented technology (and not on Georgia-Pacific factors applied in the "hypothetical negotiation" analysis), then the remedy for patent infringement would not change after the patent is assigned or sold to a third party.

\section{F. IS RAND STILL RELEVANT?}

By asserting that reasonable royalties mandated by RAND commitments should be calculated in the same manner as reasonable royalties for patent damages purposes and that patents subject to RAND commitments should be treated in the same manner as patents that are not subject to RAND commitments, we do not mean to imply that there is no value in RAND commitments. On the contrary, we believe that RAND commitments and other patent pledges serve several important purposes.

First, as discussed in Part I, when a patent is subject to a RAND commitment, the likelihood that a court will grant the patent holder an injunction to prevent further infringement is lower than it would be absent the RAND commitment. The fact that the patent holder made the RAND commitment strongly suggests, when applying the eBay analysis, that the patent holder will not be irreparably harmed absent an injunction and will be adequately compensated by monetary damages (i.e., a reasonable royalty) if an injunction is not granted.

Second, a patent holder's violation of a RAND commitment may give rise to damages or other remedies in favor of the infringer/potential licensee. It is interesting to note that in both Microsoft $v$. Motorola and Apple v. Motorola, patent holder Motorola was the defendant in suits alleging breach of contractual duties to the infringers, Motorola's potential

patented technology and its use, and not specifically on whether the patent owner has made a RAND commitment.

165. See NAS REPORT, supra note 10, at 81-93. 
licensees. ${ }^{166}$ In Microsoft, Microsoft won specific performance, which involved Motorola's granting of a license at the RAND rate (as determined by Judge Robart). ${ }^{167}$ This is not to say, however, that other damages with respect to Motorola's alleged breach of contract, bad faith, fraud or anticompetitive behavior, if established, might not also have been available to potential licensees.

Third, RAND commitments serve an important private ordering function by encouraging broad licensing of patents rather than patent infringement litigation and thereby reducing transaction costs. Thus, even if the royalty that a patent holder may charge to a licensee under a RAND commitment is the same as the royalty it would have received as damages in an infringement suit absent the RAND commitment, it is more efficient to operate under a system in which there is a presumption that licenses will be granted on reasonable terms compared to a less certain environment in which disputes are more likely to be pursued in litigation.

Finally, in most cases a patent holder's RAND commitment extends to all implementers of a particular standard rather than only to firms that are the members of the relevant SSO ${ }^{168}$ RAND commitments thus establish a broad class of parties entitled to receive licenses from the patent holder and, by the same token, create a broad category of firms having standing to enforce such commitments against non-compliant patent holders. ${ }^{169}$

\section{CALCULATING REASONABLE ROYALTIES: A NEW, OLD APPROACH TO PATENT DAMAGES}

The preceding discussion identifies many economic characteristics relevant to the determination of infringement damages that are common to both SEPs and non-SEPs. Both types of patents may require an allocation of value to isolate the contributions of the patents to the overall value of the products that implement the patented technology. For both SEPs and non-SEPs, implementers may make investments that are

166. See Microsoft Corp. v. Motorola, Inc., No. C10-1823JLR, 2013 WL 2111217 (W.D. Wash. Apr. 25, 2013); Apple Inc. v. Motorola, Inc., 869 F. Supp. 2 d 901 (N.D. Ill. 2012), aff d in part, 757 F.3d 1286 (Fed. Cir. 2014).

167. Microsoft, 2013 WL 2111217, at *101.

168. See Jorge L. Contreras, A Brief History of FRAND: Analyzing Current Debates in Standard Setting and Antitrust Through a Historical Lens, 80 ANTITRUST L.J. 39 (2015); Bekkers \& Updegrove, supra note 7, at 28.

169. Under various theories including contractual third party beneficiary and promissory estoppel, a third party implementer of a standard may have the right to enforce a RAND commitment against a patent holder that has failed to grant it a patent license on RAND terms. See Contreras, supra note 50, at 499. 
specific to the patented technologies prior to the beginning of the alleged infringement. Courts have addressed these issues in the context of infringement damages for SEPs. We propose a framework for the evaluation of patent damages that is common to both SEPs and nonSEPs. This common framework relies on recent court opinions and scholarship relating to RAND royalties for SEPs. In addition, it relies on judicial precedents for the determination of patent damages (for nonSEPs) that existed for nearly a century before Georgia Pacific. These precedents focused on the incremental value of the patented technology relative to its next-best substitute, which we endorse as a plank in our proposed common framework.

\section{A. InCREMENTAl VAlue REDUX}

As noted above, before the advent of the Georgia-Pacific hypothetical negotiation framework, courts largely based the determination of reasonable patent royalties on the incremental value of the patented technology. ${ }^{170}$ The Supreme Court adopted this approach in Dowagiac in 1915, and courts followed it in hundreds of subsequent cases. ${ }^{171}$ But the Georgia-Pacific fifteen-factor analysis muddied the water substantially in 1970, allowing litigants and courts to focus on any number of confounding factors that distracted from the core inquiry regarding the value of the patented technology. ${ }^{172}$ Only recently in cases involving the calculation of RAND royalty rates for standard-essential patents have courts begun to realize that the incremental value of the patented technology is, and should be, the core inquiry when assessing reasonable patent royalties. Thus, as noted by the Federal Circuit in Ericsson v. D-Link,

There is no Georgia-Pacific-like list of factors that district courts can parrot for every case involving RAND-encumbered patents .... [D]istrict courts must make clear to the jury that any royalty award must be based on the incremental value of the invention, not the value of the standard as a whole or any increased value the patented feature gains from its inclusion in the standard. ${ }^{173}$

170. See supra Section III.A.2.

171. Dowagiac Mfg. Co. v. Minn. Moline Plow Co., 235 U.S. 641 (1915). Citing cases include, for example, Sheldon v. Metro-Goldwyn Pictures Corp., 309 U.S. 390, 40304 (1940), and United States v. National Lead Co., 332 U.S. 319, 351n.8 (1947).

172. See supra Section III.A.3.

173. Ericsson, Inc. v. D-Link Sys., Inc., 773 F.3d 1201, 1235 (Fed. Cir. 2014) (emphasis added). 
We concur with this conclusion, but also advance the proposition that the inquiry as to SEPs should be no different than the inquiry for nonSEPs. Accordingly, we advocate a general return to the incremental value methodology for determining reasonable royalties, whether within the framework of a Georgia-Pacific hypothetical negotiation, or more generally as a question that may be answered directly by the finder of fact. ${ }^{174}$ More specifically, incremental value is the willingness to pay for one technology relative to its next best alternative. The willingness to pay can be derived from a performance benefit or cost-savings attributed to the technology, but it is not greater than the cost of inventing around the patented technology if the alternative offers similar performance benefits.

We are not alone in advocating the use of incremental value to determine reasonable royalty patent damages, as several other recent commentators have advanced similar, though not identical, proposals. Christopher Seaman, for example, suggests using the cost of an acceptable non-infringing substitute as the upper bound on a patent's incremental value. ${ }^{175}$ However, while Seaman would include the cost of switching to an alternative to arrive at this upper bound on the patent's incremental value, we exclude switching costs, as they are, in our view, unrelated to the patent's intrinsic incremental value. ${ }^{176}$

174. As indicated above, we favor the determination of incremental patent value as a factual matter, independent of the hypothetical negotiation proposed under GeorgiaPacific. However, were we to adapt our proposal for use within a hypothetical negotiation framework, additional factors would come into play. These are discussed by Lemley \& Shapiro, supra note 9, at 1999. Under a hypothetical negotiation scenario, the sociallyoptimal "benchmark" royalty rate can be expressed by the relationship $\theta B V$, where $V$ represents the incremental value of the technology to the licensee, $\theta$ represents the relative strength of the patent, and $B$ represents the relative bargaining skill of the parties (with $B=1$ indicating that the patent holder has maximal skill and the licensee has no skill, and with the Lemley-Shapiro model generally assigning $B$ a baseline value of 0.5 ). There is some debate in the literature about the magnitude and presence of $B$ in this calculation, with Elhauge and Golden each criticizing the use of $B$. See Einer Elhauge, Do Patent Holdup and Royalty Stacking Lead to Systematically Excessive Royalties?, 4 J. Competition L. \& ECON. 535, 541-45 (2008); John M. Golden, Commentary, "Patent Trolls" and Patent Remedies, 85 TEX. L. REV. 2111, 2137-38 (2007).

175. Seaman, supra note 28 , at 1661.

176. In a recent paper, Norman Siebrasse and Thomas Cotter propose a methodology for calculating patent reasonable royalty damages that has applicability in cases involving both SEPs and non-SEPs. Siebrasse \& Cotter, supra note 8. The crux of their proposal is that the value of a patent determined in a hypothetical negotiation should take into account the subsequent incorporation of the patented technology into a standard that is not due to hold-up. We agree that a standard adds value to a patent by facilitating its use with complementary patents and other inputs, but that value is apart from the value created by adoption of the standard. 
David Taylor draws a useful distinction between patent royalty damages based on the valuation of patent rights versus the valuation of patented technology and concludes that courts should continue their movement toward technology-focused damages valuations. ${ }^{177}$ We agree, and we argue that the most expedient means of doing so is by adopting the incremental value test outlined above to the smallest technology for which a stand-alone incremental value can be calculated, with an apportionment of that incremental value to the allegedly infringed patents. ${ }^{178}$

Durie and Lemley argue for a structured approach to patent damages calculations that focuses on three fundamental questions: (1) what is the marginal contribution of the patented invention over the prior art?; (2) how many other inputs were necessary to achieve that contribution, and what is their relative value?; and (3) is there some concrete evidence suggesting that the market has chosen a number different than the calculus that results from (1) and (2)? ${ }^{179}$

Judge Robart in Microsoft and Judge Holderman in Innovatio wrestled with the first two of these questions in their determinations of RAND royalties. They focused on the ex ante contributions of the patented technologies and denied the patent owner a return from the cost of switching ex post to alternatives or from the value created by adoption of the standard. In addition, they acknowledged the importance of apportioning the value of patented technologies to the values of the patents at issue. With regard to the third of Durie and Lemley's questions, they discounted the value of market evidence to the extent that observed negotiated royalties were inconsistent with the first two factors, such as royalties that captured the risk of hold-up or the value of the standard. ${ }^{180}$ The judges' approach is not inconsistent with the framework offered by

177. Taylor, supra note 28 , at $86-88,95-96,160$ (observing that damages are based on patent rights including the increased royalty that a patentee could obtain based on the threat of injunction, as well as potential treble damages and attorneys' fee awards, whereas damages based on the value of patented technology would be "the amount of money that a user of patented technology can save or otherwise obtain based upon the difference between a world where the patented technology is used and a world where the patented technology is not used").

178. While Taylor acknowledges the usefulness of valuing patented technologies on the basis of the next best alternative technology, $i d$. at 96 , this is only one of many possible damages approaches that he evaluates.

179. Durie \& Lemley, supra note 28 , at 628.

180. Id. at 629. It should be noted that negotiated royalties may understate the real value of patents that are known to be valid and infringed, as the former are typically negotiated without establishing validity and infringement. 
Durie and Lemley if one interprets market evidence as probative to the extent that it reflects the first two fundamental factors.

\section{B. NeXt Best Alternative}

Other courts have addressed the question of incremental value by looking to the cost of an acceptable non-infringing alternative. The theory behind this approach is straightforward. Assuming that a non-infringing alternative to a patented technology exists, the maximum amount that an infringer is likely to pay to license the patented technology is the cost of a functionally similar non-infringing substitute (because if the patent holder demands more than this cost, a rational infringer would switch to the noninfringing alternative). ${ }^{181}$

Judge Frank Easterbrook (sitting by designation) adopted this approach in Grain Processing Corp. v. American Maize-Products Co. ${ }^{182}$ In that case, Grain Processing held a patent claiming a method for producing maltodextrin, a food additive. American Maize produced maltodextrin according to the patented process, but soon after being informed that it infringed the patent, it switched to an alternative, non-infringing method. ${ }^{183}$ Grain Processing sued for lost profits, which the district court denied. ${ }^{184}$ Judge Easterbrook reasoned that the patent holder had foregone no profits, given that American Maize could have, and did, switch to a non-infringing alternative as soon as it became aware of the patent. ${ }^{185}$ However, he awarded reasonable royalty damages to Grain Processing. In calculating the amount of the royalty, he observed that the alternative non-infringing process was approximately $2.3 \%$ more expensive to implement than the patented process, and he explained that "the only [costs] relevant to this case are the incremental costs of avoiding infringement." ${ }^{186}$ Nevertheless, the district court set the reasonable royalty rate at 3\% based on an application of Georgia-Pacific factors 1, 12 and 15,

181. See sources cited supra note 59. If the patented technology and the noninfringing alternative allow production with different values or at different costs, the maximum amount that an infringer is likely to pay to license the patented technology would depend on these differentials as described in Section III.B, supra.

182. Grain Processing Corp. v. Am. Maize-Prods. Co. (Grain Processing I), 893 F. Supp. 1386 (N.D. Ind. 1995), rev'd, 108 F.3d 1392 (Fed. Cir. 1997) (unpublished table decision), judgment entered at 979 F. Supp. 1233 (N.D. Ind. 1997), affd, 185 F.3d 1341 (Fed. Cir. 1999) (Grain Processing II).

183. Grain Processing I, 893 F. Supp. at 1389.

184. Id.

185. Id. at 1392.

186. Id. 
evidencing a reluctance to base the entire royalty rate on the opinion of a single expert witness. ${ }^{187}$

The availability of the substitute technology was raised again on appeal, when the Federal Circuit considered the district court's holding with respect to lost profits. ${ }^{188}$ The Federal Circuit found that the presence of a non-infringing alternative did not preclude an award of lost profits but also concluded that the cost of the "next-best available alternative[]" was probative of "the market value of the patent owner's exclusive right." 189

Though the Federal Circuit's holding in Grain Processing generally speaks to lost profits damages, it, coupled with the district court's ruling on reasonable royalties, has been viewed as an important guidepost in the determination of reasonable royalties. ${ }^{190}$ In this respect we agree with Judge Easterbrook's reasoning: a reasonable royalty should be based on the incremental value of the patented technology, and the cost of an available, functionally similar non-infringing substitute should be a good indicator of that incremental value. This being said, other valid measures for incremental value may be found. But regardless of the particular approach to estimate incremental value, our principal recommendation is that the analytical framework for estimating infringement damages should apply to both SEPs and non-SEPs.

\section{CONCLUSION}

The interpretation of a "reasonable royalty" in the context of a patent with a RAND commitment has gathered enormous attention from policymakers, academics, and the courts. To a great extent the debate has attempted to reconcile the contrasting views of innovators and implementers with divergent perspectives on the meaning of "reasonable." Yet largely forgotten in this debate is the common intersection of factors that are relevant to a reasonable royalty for non-SEPs as well as for SEPs.

Courts have recognized that the traditional Georgia-Pacific factors must be modified to account for an economic interpretation of a RAND commitment. In particular, for a RAND-encumbered patent, the "hypothetical negotiation" in Georgia-Pacific must recognize the incremental contribution of the patented technology and how that would

187. Id.

188. See Grain Processing II, 185 F.3d 1341.

189. Id. at 1351.

190. See Nathaniel C. Love, Nominal Reasonable Royalties for Patent Infringement, 75 U. CHI. L. REV. 1749, 1761 (2008); Seaman, supra note 28, at 1713-14. 
inform a relevant negotiation that takes place ex ante, before firms and consumers make investments that are specific to a standard. In the context of RAND litigation, courts also have recognized that the incremental value analysis must apportion the value of the infringing products to the patents at issue and avoid royalty-stacking. However, we note that there is nothing new about a focus on the incremental value of a patented technology in the assessment of a reasonable royalty. In fact, courts have long emphasized incremental value in their evaluation of damages for patent infringement. The central role of incremental value faded from view only after the emergence and popularization of the fifteen GeorgiaPacific factors.

We argue that incremental value is the appropriate framework to evaluate reasonable royalties for both SEPs and non-SEPs. A unified framework for infringement damages based on incremental value provides appropriate royalty compensation for all infringed patents and avoids many of the concerns that arise if SEPs are held to a different standard for assessing reasonable royalties. 